\title{
Crédito Privado antes da Grande Depressão do Século XX: O Mercado Hipotecário ^
}

O instrumento particular de dívida se chama assinado, conhecimento, clareza. O signatário se compromete geralmente a fazer o pagamento ao credor que nomeia, ou a quem lhe este mostrar, todas as vezes que lho pedir. [...] Muitíssimos negócios, todavia, se concluem e liquidam sem documento de qualquer espécie. Para prová-los não há precisão 'tirar testemunhas'. Operações avultadas se realizam amiúde sem clareza, debaixo de confiança, por fiar eu de sua palavra e ele da minha, como diz um contemporâneo. (Machado, 1980, p. 147-148)

\section{Renato Leite Marcondes}

Professor - Faculdade de Economia, Administração e Contabilidade de Ribeirão Preto (FEA/RP) Endereço: Av. dos Bandeirantes, 3900, C.1 Sala 62 - Ribeirão Preto/SP - Brasil

CEP: 14040-905 - E-mail: rlmarcon@usp.br

Recebido em 14 de agosto de 2012. Aceito em 14 de maio de 2014.

\section{Resumo}

Apesar das restrições existentes, o mercado hipotecário cresceu no Brasil ao longo do século XIX e início do século XX. As mudanças institucionais possibilitaram a expansão do mercado por meio de bancos e de particulares, principalmente a partir da década de 1870. Houve um avanço do sistema bancário, especialmente ao final do século XIX. A presença de instituições estrangeiras ressaltou-se no início do século XX. Não obstante estas transformações do período em estudo, o mercado hipotecário ainda se concentrava nas mãos de agentes privados. A quase totalidade das transações ocorreu entre indivíduos, especialmente no meio urbano mesmo antes de 1930. No início do século XX, quando havia um sistema bancário mais avançado, os emprestadores particulares ainda realizavam mais transações do que os bancos.

\section{Palavras-Chave}

Hipoteca, Crédito, Mercado Financeiro, Bancos, Capitalistas

- Agradeço o apoio do projeto Cátedras IPEA/CAPES para o Desenvolvimento, bem como da Fapesp (2007/00429-6 e 2012/09121-2) e CNPq (400630/2010-9) para a coleta e processamento das informações. Adicionalmente, agradeço também aos bolsistas Gustavo Cortes Gonçalves, Eduardo Arakaki, Amanda Cristine Ferracino e Souza, Marcos Andrade Alves e Victor Augusto de Almeida Oliveira pela ajuda na coleta das informações. 


\begin{abstract}
Despite the existing restrictions, the mortgage market grew up in Brazil throughout the nineteenth century and beginning of XX. The institutional changes made possible the market expansion by means of banks and private agents, mainly during the second half of nineteenth century. There was an advance of the banking system, especially at the end of the nineteenth century, even with the expressive presence of foreign institutions at the beginning of the twentieth century. Although these transformations occurred in the period of the study, the mortgage market was still concentrated in the hands of private agents. Almost the totality of transactions happened between individuals. Even at the beginning of the twentieth century, when there was an advance in the banking system, the moneylenders still performed a much more significant quantity of mortgage transactions than the banks.
\end{abstract}

\title{
Keywords
}

Mortgage, Credit, Financial Market, Banks, São Paulo

\section{JEL Classification}

N26

\section{Introdução}

O sistema bancário demorou a se formar no Brasil, pois apenas ao final do século XIX havia um conjunto significativo de instituições bancárias nas principais cidades brasileiras. O primeiro banco do Império português foi o Banco do Brasil, criado em 1808. Contudo, ele faliu poucos anos depois da independência. Esse banco e seus sucessores operavam principalmente como bancos emissores e realizavam financiamentos comerciais de forma mais restringida. $\mathrm{Na}$ ausência dos bancos, outras pessoas e instituições atuavam como fornecedores do crédito naquela sociedade colonial e imperial. Mesmo no início do século XX, grande parcela dos negócios era efetuada fora do sistema bancário. Em todo o período em questão, a agricultura constituía a principal atividade econômica do país, mas os agricultores reclamavam, como atualmente, constantemente da falta de capitais em condições facilitadas. A partir da segunda metade do século XIX, o crescimento urbano demandou grandes recursos, atendidos também por diferentes ofertantes como veremos adiante.

Este artigo propõe realizar uma discussão do desenvolvimento do mercado de crédito privado no Brasil até o início do século XX. Numa primeira seção, discutimos, calcado na literatura disponível, o desenvolvimento do financiamento brasileiro de modo mais am- 
plo desde o período colonial até 1930, enfatizando os aprimoramentos da legislação que tentava minorar os problemas do mercado de crédito, em especial a legislação hipotecária de 1864. A hipoteca representou uma possibilidade de proteção tanto para os credores nacionais quanto estrangeiros, bem como bancos, empresas e pessoas físicas. Na segunda seção, caracterizamos o mercado hipotecário de forma mais geral, ressaltando em alguns recortes as regiões mais destacadas. Procuramos demonstrar a importância desse mercado e a regularidade de transações ao longo do tempo. Por fim, analisamos mais aprofundadamente o mercado de crédito hipotecário e as condições de financiamento (prazos, juros e valores) para a cidade de São Paulo, especialmente microdados do mercado de 1865 a $1920 .{ }^{1}$ Como a maior parte dos estudos aborda a atuação dos bancos, destacamos a participação deles e de outros agentes na oferta de crédito, especialmente os denominados capitalistas, que emprestam dinheiro a juro. Deste modo, poderemos avaliar a atuação dos diferentes agentes nesse mercado por meio da análise das hipotecas. Procuramos demonstrar a importância desse instrumento e de agentes privados, bancários ou não.

\section{Crédito, Legislação e Hipoteca}

Além da escassez de capitais típica de uma sociedade no início do seu desenvolvimento, as restrições legais dificultaram o funcionamento do mercado de crédito na colônia, particularmente o controle dos juros e das execuções, em virtude dos privilégios concedidos aos senhores de engenho e mineradores de não arrematação de suas fábricas e de seus escravos (ver Brito, 1923, p. 104). Por outro lado, os limites do juro decorriam da interferência religiosa e real, especialmente contra os abusos da usura no espaço ultramarino. Nas Ordenações Filipinas do início do século XVII, os contratos usurários foram reprimidos. $\mathrm{Na}$ época pombalina e depois do terremoto de Lisboa, o alvará de 17 de janeiro de 1757 impôs o teto de 5\% ao ano de juros legais para a cobrança dos empréstimos.

1 Tais dados foram coletados nos livros do $1^{\circ}$ Cartório de Imóveis da capital paulista depositados no Arquivo Público do Estado de São Paulo (APESP) por meio de outra pesquisa denominada Crédito hipotecário em São Paulo: séries históricas (1865-1920), apoiada pelo CNPq e FAPESP. 
Apesar do desenvolvimento durante o século XVIII principalmente em razão dos descobertos do ouro, existia a dificuldade da instalação de instituições específicas de crédito em todo o país, distintas das ordens religiosas, dos negociantes, dos comerciantes, dos capitalistas e dos Juízos dos Órfãos (ver Schwartz, 1988 e Sampaio, 2000). Outra característica do crédito no período colonial foi manter um alcance local e com a predominância de relações pessoais, devido à assimetria de informações e aos riscos associados às flutuações das colheitas e dos preços dos produtos agrícolas (ver Faria, 1998, p.188).

As hipotecas já eram realizadas no período colonial, porém as dificuldades para o funcionamento do mercado de crédito colonial restringiam as possibilidades de financiamento. Como declarado pelo desembargador João Rodrigues de Brito no início do século XIX, ele lamentava as "vergonhosas delongas" judiciais que não contribuíam para a solução dos conflitos e cumprimento dos contratos. Tal fato aumentava a demora no reembolso dos credores e afastava os capitais do mercado: "obrigando-os a não largarem de si a administração de seus dinheiros, posto que menos produtivos na sua mão, do que o seriam empregados por hábeis lavradores." (Brito, 1923, p. 108-109). De acordo com o autor, a falta de um registro de hipotecas resultava em não poder "nunca o credor conhecer a solidez das que lhe oferecem, ficando sempre exposto às burlas dos velhacos, que obrigam o mesmo prédio a dois ou três, deve em consequência perpetuar-se aquele descrédito geral dos devedores pobres, ainda que tenham hipotecas livres, uma vez que a legislação atual não deixa provar que o são." (Brito, 1923, p. 107)

A estrutura de crédito colonial tendeu a se modificar antes mesmo da independência, a partir do início das atividades do Banco do Brasil em 1808 e posteriormente dos bancos provinciais. ${ }^{2}$ Ocorreu uma tentativa de controle monetário e aumento da oferta crédito. Após a independência, o Banco do Brasil não resistiu às pressões econômicas dos primeiros anos do país. Posteriormente, houve várias tentativas do estabelecimento de instituições bancárias, iniciada, em 1834, com a Caixa Econômica da Bahia e depois com o Banco do Ceará em

2 Na passagem do século XVIII para o XIX, o ambiente institucional mostrava-se relativamente comum entre Portugal e Brasil, dificultando a criação de bancos. Como afirma Pinto de Aguiar, "Portugal foi dos países europeus que mais demoraram a organizar estabelecimentos bancários específicos" (1960, p. 9). O primeiro Banco do Brasil foi criado em 1808 e o de Lisboa em 1821. 
1836 e o Banco Comercial do Rio de Janeiro em $1838 .{ }^{3}$ Os limites de juros começaram a ser suprimidos em 1810 para o comércio marítimo e posteriormente para as demais operações. ${ }^{4}$

Não obstante as novas instituições bancárias e legais, as condições dos financiamentos no início do Império não eram compatíveis com as exigidas pela lavoura, principalmente com relação aos prazos e às taxas de juros. Tal fato inviabilizava a tomada de financiamentos diretamente junto aos bancos por parte dos agricultores, até mesmo dos emergentes cafeicultores naquela época, favorecendo a atuação de intermediários, os quais conseguiam recursos bancários ou não e emprestavam àqueles por prazos maiores. A proximidade e, muitas vezes, a ligação pessoal entre o intermediário comercial, denominados como comissários, e o cafeicultor facilitaram a extensão de laços financeiros. Devido a esse alongamento dos prazos e ao spread absorvido por esses intermediários, a taxa de juros tendeu a ser muito elevada. No caso específico da cafeicultura, os intermediários responsáveis pela comercialização da produção cafeeira também atuavam no fornecimento de financiamentos à atividade cafeeira. ${ }^{5} \mathrm{~A}$ melhora do sistema de comunicações e transportes principalmente com a navegação a vapor e as ferrovias também incentivou a concentração dos negócios na praça carioca, em detrimento de negociantes no interior.

Bernardo de Souza Franco aponta, em 1848, claramente as dificuldades de crédito da lavoura, principalmente a mais longo prazo ( $c f$. Franco, 1984). Nesse sentido, a partir de meados do século XIX tomaram-se medidas institucionais modernizadoras, que beneficiaram o mercado de crédito brasileiro. ${ }^{6} \mathrm{O}$ princípio dessas mudanças ocorreu com a criação do registro geral de hipotecas na lei orçamentária de 1843, porém houve a necessidade de aguardar a sua regulamentação posterior. Somente com o decreto de 1846 regulamentou-se o registro geral de hipotecas, já estabelecendo a inscrição concentrada na comarca onde se situam os bens hipotecados e a prioridade de

3 Ver Levy \& Andrade (1985, p. 17-48). Destes o Banco Comercial detinha o maior capital, integralizando cinco mil contos.

4 De acordo com o alvará de 5 de maio de 1810 e a lei de 24 de outubro de 1832 . Esta última retirou toda a restrição aos juros, sendo os que as partes convencionarem em escritura ou na falta os juros legais de $6 \%$ ao ano.

5 Marieta de Moraes Ferreira (1977) salientou esta mudança na praça carioca.

6 Tal mudança ocorreu conjuntamente à modernização mais geral da legislação, compreendendo o código comercial, a lei do final do tráfico atlântico de escravos e a de terras todas em 1850 . 
acordo com a ordem. ${ }^{7} \mathrm{O}$ aprimoramento das hipotecas constituía uma forma de tentar melhorar as condições do financiamento.

As mudanças institucionais daquele momento produziram, assim, um momento de expansão dos negócios durante a década de 1850 , especialmente urbanos. Um novo Banco do Brasil foi formado por particulares, inicialmente liderados pelo Barão de Mauá. Diversas sociedades acionárias autorizadas pelo governo foram constituídas para diversas finalidades bancárias ou não, porém muitas dessas instituições nunca se instalaram ( $c f$. Soares, 1865b, p. 54). Os capitais realocados do tráfico africano incrementaram os fluxos bancários, porém poucos hipotecários, ver por exemplo Saes (1986) ou Hanley (2005). Ao discutir a crise comercial de 1864, Sebastião Ferreira Soares criticou a reduzida importância do crédito hipotecário entre os oito bancos então existentes, dos quais cinco provinciais. Tais instituições realizavam apenas descontos e depósitos a prazos curtos, até mesmo o Banco Rural e Hipotecário, criado no início da década de 1850, "mui pequena parte do seu capital emprega em hipotecas da propriedade urbana do município da corte" (1865a, p. 38). ${ }^{8}$ A criação do registro não foi suficiente para o crescimento do crédito hipotecário, em razão da reduzida publicidade e da falta de especialidade objetiva.

Os excessos dessa década de 1850 conduziram o governo a reduzir as emissões monetárias dos bancos e a restringir à associação de capitais por meio da lei dos "entraves" de 1860, exigindo um capital mínimo subscrito das companhias para as ações serem negociadas em bolsa. ${ }^{9}$ De outro lado, esta lei fez menção à criação de caixas econômicas públicas, como modo de mobilização de poupança para os pequenos depositantes com segurança. Por fim, ela referiu-se também à criação de Montepios, Monte Socorros e Socorros Mútuos, destinadas à realização de penhores. A Caixa Econômica e o Monte Socorro da capital do Império foram implantados no ano seguinte e posteriormente nas principais capitais províncias. ${ }^{10}$

As mudanças ainda não produziram uma alteração expressiva do mercado de crédito, especialmente o hipotecário. O jurista Perdigão Malheiros salientava as dificuldades para a concessão de emprésti-

Decreto 482 de 17 de novembro de 1846.

8 Ver também Carlos Gabriel Guimarães (2007) e Theo Piñero (2007).

9 Lei 1.083 de 22 de agosto de 1860.

10 Decreto 2.723 de 12 de janeiro de 1861 . 
mos e execução dos créditos não pagos (1865, p. IV-V). As restrições do crédito rural também foram partilhas pelos próprios agricultores. Em seu estudo sobre este tema na década de 1850, o cafeicultor Luís Peixoto de Lacerda Werneck afirmava que os juros mais elevados para a agricultura decorriam dos riscos maiores de reembolso e execução dos empréstimos para esta atividade em relação às demais (Werneck, 1857, p. 15).

Uma resposta a estas dificuldades foi a legislação hipotecária de 1864 e o regulamento do ano seguinte, que permitiram maiores garantias aos fornecedores de empréstimos. Esta reforma ampliou a publicidade das hipotecas por meio de um novo registro geral e da inscrição/transcrição das transmissões e de ônus reais das propriedades suscetíveis de hipoteca. O novo registro favoreceu o estabelecimento da publicidade formal dos créditos em livros específicos. O objeto da hipoteca podia compreender os imóveis e seus respectivos acessórios e, no caso agrícola, escravos e animais. ${ }^{11}$ Ele passou a especificar as características do colateral e do crédito (valor, prazo e juros). A especialidade da dívida permitiu conhecer o comprometimento do imóvel com o crédito e a possibilidade de novas hipotecas a partir daquela garantia. ${ }^{12} \mathrm{~A}$ partir desse novo quadro institucional, o crédito expandiu-se na até o final do Império. ${ }^{13}$

Apesar da reforma legal e do início dos registros hipotecários de forma mais organizada, os volumes destinados pelos bancos aos empréstimos à lavoura continuaram restritos, apenas o Banco do Brasil se adaptou com uma nova carteira hipotecária independente da comercial em 1866, e começou a operar mais expressivamente na década de $1870 .{ }^{14}$ Para incrementar os montantes, houve sugestões de

${ }^{11}$ A lei 1.237 de 24 de setembro de 1864 foi publicada poucas semanas após a crise bancária. Ela afirmou: "A hipoteca convencional deve indicar nomeadamente o imóvel ou imóveis em os quais ela consiste, assim como a sua situação e característicos." Os acessórios dos imóveis agrícolas abarcariam instrumentos da lavoura e os utensílios das fabricas respectivas, aderentes ao solo. Ela aboliu os privilégios de execução do senhor de engenho ou minerador, que se iniciaram ainda no período colonial.

${ }^{12}$ A lei obrigava os empréstimos hipotecários a não excederem à metade do valor dos imóveis rurais e três quartos dos urbanos. Ademais, as sociedades credoras poderão lançar letras hipotecárias para se financiar, desde que autorizadas pelo governo.

${ }^{13}$ Ver, para o Rio de Janeiro, Ryan (2007, p. 33).

${ }^{14}$ Ver Piñero (2007, p. 47-58). De acordo com as informações recolhidas por Goldsmith (1986, p. 39), o Banco do Brasil mantinha 31,2\% dos seus ativos em empréstimos hipotecários em junho de 1871. As hipotecas revelaram-se mais importantes na carteira do banco do que os títulos públicos nesse momento. Contudo, a tendência não foi mantida, pois em junho de 1881 reduziu-se a 22,4\% e em junho de 1889 a 15,0\%. De toda sorte, a atuação do Banco do Brasil no mercado de hipotecas foi bastante destacada. 
utilizar os bancos de emissão e as caixas dos órfãos e as econômicas para adquirir as letras hipotecárias, esperando até mesmo a atração de capitais estrangeiros. O decreto de 1875 procurou atender a esta demanda, incentivando o surgimento de bancos de crédito real e, desse modo, o próprio crédito para a lavoura por meio da garantia de juros. A demora na instalação de tais bancos salientou os problemas levantados no Congresso Agrícola, especialmente das dificuldades de atração dos capitais e de cobrança das dívidas. A solução proposta no Congresso foi permitir a emissão de moeda por estas instituições de crédito agrícola para financiar a lavoura. Não obstante a nova legislação, a constituição dos primeiros bancos de crédito real demorou vários anos para ocorrer. ${ }^{15} \mathrm{~A}$ lei ainda não resolveu a diferença entre o custo da capitação e aplicação do recurso para o banco. Ao final dessa década, no Congresso Agrícola o problema do crédito assumiu caráter central nas discussões, ver Ferreira (1977, p. 43).

Os agricultores e congressistas ainda reclamavam das dificuldades para o crédito rural, especialmente em função da ausência de um cadastro das terras e a desordem dos títulos de propriedade. Não obstante as dificuldades de mobilização dos recursos e os problemas de cobrança cara e morosa na justiça, pouco a pouco o crédito hipotecário expandiu-se, principalmente nos maiores centros urbanos, que cresceram significativamente ao final do século XIX e início do $\mathrm{XX}$. O avanço do crédito bancário por meio de hipotecas atingiu as regiões cafeicultoras nas décadas de 1870 e 1880, centrado no Banco do Brasil que já atuava nesse mercado desde o final da década de $1860 .{ }^{16}$

${ }^{15}$ Em meio a crise de 1875 , o decreto 2687 de 6 de novembro concedia garantia de juros de até $5 \%$ ao ano ao banco de crédito real que se fundasse no Império de acordo com a Lei de 1864. Este banco deveria emprestar a taxa de juros limite de $7 \%$ e a prazo de 5 a 30 anos. Posteriormente, o governo do Estado de São Paulo aprovou uma lei elevando a garantia de juros para 6\% em 1881, facilitando a formação do banco paulista. Contudo, apenas em 1882 foram aprovados os estatutos do Banco de Crédito Real de São Paulo e do Império do Brasil, consistindo nos dois primeiros desta natureza fundados no Brasil.

${ }^{16}$ C. F. Van Delden Laërne (1885, p. 218-223) analisou, na época, os empréstimos hipotecários de uma amostra de fazendas de café em 1883, infelizmente desconhecemos o universo total dos empréstimos. Assumindo que fossem apenas estes os empréstimos bancários por hipotecas para a cafeicultura, o conjunto analisado alcançou pouco mais de mil fazendas de café e quarenta mil escravos, abarcando fazendas do Rio de Janeiro, Minas Gerais, Espírito Santo e São Paulo. O Banco do Brasil realizou ao redor de três quartos do total das hipotecas $(74,7 \%)$, compreendendo mais de quatro quintos do total emprestado $(81,8 \%)$. As outras instituições financeiras foram o Banco de Crédito Real de São Paulo e o Banco Predial, mais atuantes na província de São Paulo e Rio de Janeiro respectivamente. As hipotecas realizadas corresponderam a pouco menos da metade dos valores estimados para as fazendas $(44,6 \%)$. Ver também Piñero (2007) a respeito da carteira hipotecária do Banco do Brasil. 
Diferentes agentes adaptavam-se às novas condições e utilizavam-se das hipotecas como proteção para seus financiamentos, não se restringindo aos bancos nacionais ou estrangeiros. Como veremos adiante, os capitalistas, comerciantes e negociantes mantinham uma participação bastante expressiva nesse mercado. De outro lado, as maiores empresas financiavam-se por meio de ações e títulos colocados no mercado nacional ou internacional, como as ferroviárias. Uma parte desses títulos detinha garantias imobiliárias das empresas registradas em hipotecas. Desta forma, o mercado hipotecário mostrou-se mais amplo do que o crédito imobiliário rural ou urbano, compreendendo muitas vezes o comercial e até mesmo o industrial. Por fim, alguns lançamentos de debêntures que procuravam melhores garantias para o credor também se fizeram por meio de hipotecas.

Durante o período denominado Encilhamento na passagem do Império para a República, a política executada produziu grande repercussão na economia, finanças e balança de pagamentos. Num período de mudança institucional com a abolição da escravatura e disseminação do trabalho livre, a flexibilidade da política monetária ocorreu, principalmente, por meio de novos bancos emissores, iniciada em 1888 e atingindo o seu ápice em 1892. A partir desse último ano o governo começou a conter os excessos do período, porém a restrição mais forte da política monetária ocorreu a partir de 1898 com Joaquim Murtinho (ver Franco, 1983 e 1990 e Schulz, 1996). Há também uma discussão na literatura sobre o impacto positivo do Encilhamento para a industrialização brasileira (ver uma revisão em Levy, 1989 ou para São Paulo em Lerias, 1988). ${ }^{17}$ Destarte, ao avaliarmos as informações disponíveis acerca do mercado financeiro poderemos notar as consequências das políticas econômicas e legislações da época, como desse período.

A restrição monetária produziu uma crise bancária e financeira na passagem do século XIX para o XX, vitimando várias instituições financeiras, especialmente nacionais. O recém criado Banco da República passou por dificuldades e motivou uma intervenção do governo. Desse modo, formou-se um novo Banco do Brasil em 1905, que se revelou um marco de uma nova etapa da evolução do sistema financeiro. A partir desse momento a instituição tornou-se uma empresa mista, sendo o maior acionista a União.

${ }^{17}$ Decreto 3.272 de 5 de outubro de 1885 e o 169 A de 19 de janeiro de 1890. Este último menciona explicitamente a hipoteca de engenhos centrais, fábricas, usinas, oficinas e ferrovias, abrangendo edifícios e maquinismos. 
Este novo banco expandiu seus negócios expressivamente, bem como o setor bancário como um todo, até mesmo os bancos estrangeiros (cf. Triner, 2000).

A política econômica assumida pelo governo condicionou a disponibilidade de crédito na economia. Além dos momentos de expansão e crise já apontados, o padrão-ouro também restringiu a política monetária e creditícia ainda no Império durante uma parte do Segundo Reinado (1840-1889) e, na Primeira República (1889-1930), em duas oportunidades: a primeira por meio da Caixa de Conversão de 1906 a 1914 e a segunda pela de Estabilização de 1926 a $1930 .{ }^{18}$ O câmbio fixo tão defendido naquele momento perdurou pouco tempo no Brasil, em função das flutuações do Balanço de Pagamentos.

A Primeira Guerra Mundial incentivou o crescimento das instituições nacionais públicas e privadas, descentralizando o sistema bancário, até mesmo por meio de bancos e caixas estaduais (ver Costa Neto, 2004, p. 35). Os governos estaduais passaram a auxiliar financeiramente os bancos hipotecários por meio de empréstimos e de recursos depositados nas suas Caixas Econômicas, como o de São Paulo (ver Costa, 1988, p. 80-81). De outro lado, o sistema bancário foi nacionalizado pelas reformas introduzidas a partir da década de 1920, por meio da Inspetoria Geral de Bancos, reforçadas na década seguinte pelas constituições de 1934 e 1937. Assim, os bancos estrangeiros foram muito importantes para o sistema financeiro do final do século XIX e início do XX, mas reduziram sua participação no sistema nacional a partir desse momento. O sistema bancário como um todo elevou sua participação no PIB, atingindo os empréstimos pouco mais de um quinto do produto total em 1929 (cf. Goldsmith, 1986, p. 167).

Como verificou Aldo Musacchio (2009), as companhias brasileiras adaptavam-se aos diferentes arranjos institucionais, combinando formas diversas de financiamento por meio de emissões de ações e títulos. Apesar das restrições da política econômica e externas, havia mercados importantes no país de títulos privados e de ações até a década de 1920. Nessa época as companhias de diferentes setores emitiram títulos e ações no mercado, garantidos por um ambiente institucional de proteção aos credores e acionistas. As mudanças

${ }^{18}$ Durante o Segundo Reinado buscou-se manter um câmbio fixo a partir da lei de 1846, porém as restrições mostraram bastantes fortes, especialmente durante e após a Guerra do Paraguai (1864-1870).

Estud. Econ., São Paulo, vol.44, n.4, p.749-786, out.-dez. 2014 
provocadas pela Primeira Grande Guerra e a depressão produziram, principalmente em função da retração dos fluxos de capitais internacionais a redução dessas garantias e a dos próprios mercados de ações e títulos.

As mudanças institucionais ao longo do século XIX possibilitaram o crescimento do mercado hipotecário, constituindo uma forma do crédito privado. Apesar de não compreender o financiamento das empresas por meio das ações, ele abarca uma parte dos créditos bancários e debenturistas. De outro lado, constitui um modo de entendermos um segmento pouco estudado das empresas e principalmente das pessoas físicas credoras. Apesar de não serem bancos, as pessoas realizavam empréstimos, das quais um grande número de modo eventual, mas outras de forma regular e especializada, como os capitalistas. Na próxima seção apresentamos este importante mercado de crédito privado brasileiro.

\section{Crédito Hipotecário Brasileiro}

Os primeiros informes quantitativos disponíveis na literatura sobre o mercado hipotecário surgiram apenas a partir do final do século XIX. ${ }^{19}$ Isto se observa para algumas regiões e até para o conjunto do país, especialmente compiladas nos Anuários Estatísticos do Brasil. ${ }^{20}$ Como esperado, os primeiros informes disponíveis referem-se ao Distrito Federal, que dispõe de uma série muito interessante do número de novas hipotecas concedidas e dos valores transacionados desde 1890 até 1930 e pode ser observada no Gráfico $1 .{ }^{21}$ Notamos os principais ciclos desse mercado, refletindo as mudanças das políticas econômicas e legislações, como o boom do Encilhamento e a

${ }^{19}$ Antes da mudança da legislação hipotecária de 1864-65, Sebastião Ferreira Soares publicou uma estatística das hipotecas de 1855 a 1859, totalizando quase 68 mil contos de réis (1865b, p. 226). Embora fosse um país agrário, as hipotecas rurais foram apenas um pouco maiores em valor do que as urbanas, concentrando mais da metade das transações no município da corte e província fluminense. Destarte, o total da dívida hipotecária do Império naquele momento perfez uma parcela pequena do somatório das exportações nesses anos $(12,9 \%)$, o qual somou 525 mil contos de réis.

${ }^{20}$ Publicações realizadas pela Diretoria Geral de Estatística (DGE) e posteriormente do Instituto Brasileiro de Geografia e Estatística (IBGE).

${ }^{21}$ Infelizmente os Anuários não disponibilizaram as informações para os anos de 1910 a 1912. 
retração do final do século XIX. ${ }^{22}$ Nesse ciclo, o valor antecedeu o movimento do número, mas nas flutuações posteriores houve maior sincronia das duas variáveis, como na recuperação no início do século até Primeira Grande Guerra e na contração expressiva durante o conflito. Houve uma recuperação acentuada logo após a guerra, a qual se prolongou até $1930 .{ }^{23}$ Desse modo, os anos 1920 foram bastante promissores para o mercado de crédito da capital da República, chegando a efetuar quase três mil hipotecas num único ano ao final da década de vinte. Assim, a tendência de ambas as variáveis desse mercado manteve-se crescente desde o final da Primeira Grande Guerra até o início dos anos 1930.

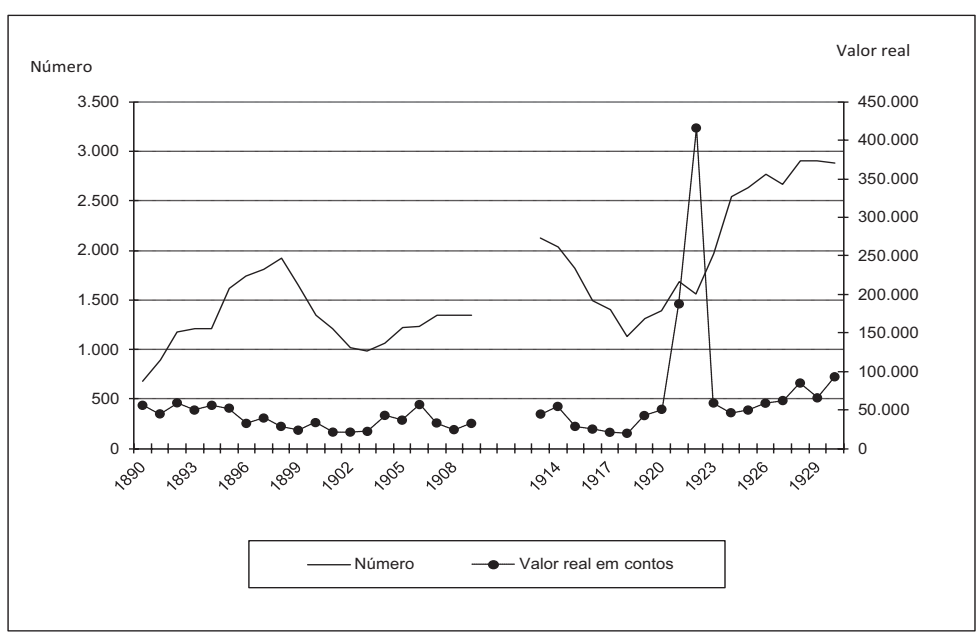

Gráfico 1 - Número e valor real das hipotecas do Distrito Federal (1890-1930)

Podemos ainda realizar uma caracterização geral das hipotecas do Distrito Federal para alguns anos que dispomos de informações mais detalhadas. Com relação à localização dos imóveis, a quase totalidade

22 O Brasil apresenta uma taxa de inflação muito elevada já naquela época. Transformamos os valores nominais de cada ano em valores reais por meio do índice de preços calculados por Catão (1992) de 1870 a 1913 e deflator do produto de Haddad (1978) de 1914 a 1930. Os valores constantes referem-se ao ano de 1913. Um conto de réis é equivalente a mil mil-réis.

23 O grande pico de valor para 1921 e 1922 não modificou a tendência apontada. Infelizmente não descobrimos o motivo desses valores extraordinários nesses anos, mas também ocorreu, em menor intensidade, em outra variável financeira: Ml. Como veremos na próxima seção, pode ser decorrente de transações excepcionais. A correlação entre número e valor mostra-se não significativa em função desses valores extraordinários $(0,128)$, porém se excluirmos esses anos já observaremos uma correlação positiva $(0,575)$. 
delas referiu-se à área urbana, perfazendo tal tipo de propriedade $94,5 \%$ do número e $85,7 \%$ dos valores em 1909. A diferença entre as participações relativas do número e valor decorreu dos maiores valores para os empréstimos com colateral de propriedades agrícolas. Para a maioria dos casos em estudo, os imóveis rurais perfizeram, em geral, um número menor de transações, porém assumiram valores médios mais elevados.

Quando pensamos em hipotecas normalmente associamos a um financiamento colateralizado a juros reduzidos e prazos longos. As taxas de juros nominais aplicadas nos financiamentos do Distrito Federal foram de $5 \%$ a $15 \%$ para a grande maioria das hipotecas $(85,3 \%)$. Das mais de mil hipotecas realizadas nesse ano de 1909, as menores taxas corresponderam a tão somente dez empréstimos com juros de até cinco pontos porcentuais ( $0,9 \%$ do total), mas que representaram $1,8 \%$ dos valores negociados. De outro lado, quase três quartos dos casos apresentaram prazos de seis meses a três anos $(74,5 \%)$. Apesar da preocupação de criar um instrumento de financiamento de longo prazo, o crédito hipotecário mantinha características mais próximas de curto e médio prazos. Os empréstimos de longo prazo (acima de 15 anos) consistiram em apenas catorze casos nesse ano de 1909 (1,1\%), porém responderam por 32,9\% dos valores transacionados. Destarte, esse resultado de menores juros e principalmente maiores prazos para poucos empréstimos e de quantias mais elevadas manter-se-á nas demais análises das hipotecas para diferentes espaços e períodos.

Para o conjunto do país, as informações concentraram-se num período mais reduzido de 1909 a 1930, conforme o Gráfico 2. Os movimentos apontados para o Distrito Federal a respeito do número e valor mantêm-se no conjunto do país de forma assemelhada, especialmente a tendência crescente das variáveis. ${ }^{24}$ Também podemos avaliar a distribuição das hipotecas no espaço brasileiro. Uma distinção interessante ocorreu com relação à região Norte, que até a Primeira Guerra mostrava um dinamismo significativo em função da borracha, representando $5,2 \%$ do número e $6,6 \%$ do valor das hipotecas brasileiras em 1909. ${ }^{25}$ Contudo, depois da Guerra, as

\footnotetext{
${ }^{24}$ A correlação dos números e dos valores das hipotecas brasileiras revelou-se significativa e assemelhada ao do Distrito Federal excluindo os anos do pico de valor $(0,515)$.

${ }^{25}$ O Acre apresentou hipotecas apenas a partir de 1913, quando já realizou 66 hipotecas. Este número superou a soma das do Maranhão e Piauí. Posteriormente houve uma retração das hipotecas efetuadas no Acre.
} 
participações reduziram-se rapidamente para menos de um ponto porcentual. De outro lado, as regiões Nordeste e Sul elevaram sua participação relativa para entre um quarto e um quinto do valor total das hipotecas do país durante a Guerra, ressaltando o papel das economias mais direcionadas para o mercado interno. ${ }^{26}$

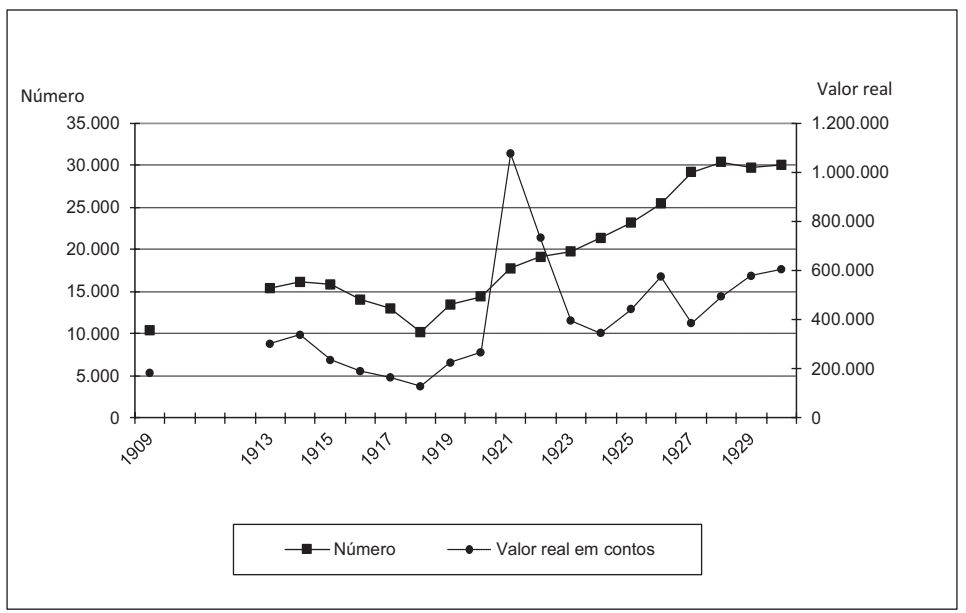

Gráfico 2 - Número e valor real das hipotecas brasileiras (1909-1930)

Em 1909, o Distrito Federal representou pouco mais de um décimo do número total das hipotecas brasileiras $(13,0 \%)$ e quase um quinto dos valores transacionados (17,9\%), salientando a importância do mercado da capital da República, mormente dos seus valores. Em 1930, o Distrito Federal correspondeu a 9,6\% do número e 15,4\% dos valores transacionados no país, demonstrando uma ligeira retração na sua participação nas duas variáveis. As capitais dos Estados e o Distrito Federal representavam quase a metade dos créditos tanto em número quanto em valor em 1909 (46,2\% e 43,7\%, respectivamente). Desse modo, como já apontado por Goldsmith (1986, p. 178), notamos também uma concentração bastante elevada do crédito hipotecário na capital da República e dos estados mais ricos.

${ }^{26} \mathrm{Em}$ 1909, as duas regiões perfizeram 25,6\% do número e 19,6\% dos valores. De outro lado, a região Centro Oeste representou, nesse ano, menos de um ponto porcentual das duas variáveis consideradas. 
Apesar da importância elevada da agricultura na economia brasileira daquela época, as hipotecas urbanas para o Brasil mostraram-se, já em 1909, maior do que as rurais, tanto em valor $(53,4 \%)$ quanto especialmente em número $(66,3 \%) .{ }^{27}$ Como esperado, o universo rural apresentava, em comparação com a realidade do Distrito Federal, maior importância nos Estados. Acompanhando as mudanças da própria economia como um todo, a tendência ao longo do tempo apontou um maior dinamismo do meio urbano no período analisado, que atingiram pouco mais de dois terços do número total do país $(69,9 \%)$ e pouco menos de dois terços do valor $(59,6 \%)$ em 1929. Nesse último ano, os valores médios ainda se mostraram bastante superiores para as hipotecas rurais em comparação com as urbanas, perfazendo uma diferença de mais da metade. Apesar da maior presença de hipotecas rurais do que no Distrito Federal, os prazos dos empréstimos continuaram concentrados em até 3 anos, que representaram pouco mais de três quartos do total de hipotecas tanto em 1909 como em 1929. ${ }^{28}$ Assim, notamos uma tendência de transformação da economia e do crédito no período em questão, ocorrendo uma valorização relativa das propriedades urbanas.

O mercado hipotecário ainda se mantinha bastante apartado do sistema bancário em 1909, pois os bancos perfaziam tão-somente 7,5\% do número de hipotecas e 17,5\% dos valores negociados. Muitas capitais dos Estados não efetuaram o registro de hipoteca por estabelecimento de crédito nesse ano, como Belo Horizonte e Curitiba. ${ }^{29}$

${ }^{27}$ Em 1914, o resultado revelou-se semelhante em termos de número $(68,0 \%)$, porém em valor as hipotecas rurais foram mais importantes do que as urbanas, que representaram $46,6 \%$. $\mathrm{O}$ avanço da agricultura no período refletiu-se na mudança do perfil do crédito.

28 As condições dos empréstimos podem ser caracterizadas de modo mais geral. As hipotecas com prazo superiores a 15 anos, que representaram uma pequena parcela do número total (apenas 0,5\% em 1909 e 1,3\% em 1929), mas, como eram em montantes bem mais elevados, representavam $16,4 \%$ e $8,6 \%$ dos valores totais desses idênticos anos. De outro lado, as hipotecas com taxas de juros inferiores a quinze pontos porcentuais revelaram-se a maioria dos casos, atingindo $85,3 \%$ e $72,0 \%$ em idênticos anos, respectivamente. Por fim, em valor, estas últimas hipotecas alcançaram parcelas superiores: 96,0\% e 92,3\%, salientando os valores um pouco maiores delas, principalmente em 1929.

29 Apesar do registro cartorário do Anuário Estatístico não indicar hipoteca para a então nova capital de Minas Gerais, sabemos pelo trabalho de Anderson Pires da existência bastante atuante do Banco de Crédito Real de Minas Gerais na região de Juiz de Fora (2009, p. 221). Segundo dados do autor levantados nos livros cartorários da cidade, este banco realizou 58 hipotecas em Juiz de Fora em 1909, representando a totalidade das hipotecas bancárias registradas em Minas Gerais de acordo com o Anuário. Esta comparação salienta também uma discussão sobre o critério de classificação como banco e a qualidade das informações, especialmente dos dados mais desagregados dos Anuários. Quando comparamos os dados informados nos Anuários para a capital de São Paulo e os por nós coletados nos livros cartórios que veremos adiante, verificamos que o número total de hipotecas mostrou-se semelhante, porém o número hipotecas de estabelecimentos de crédito mostrou-se grande divergência, 
O maior número de transações por meio de bancos não ocorreu no Distrito Federal nesse ano (13,3\%), mas em São Paulo (26,9\%), Rio Grande do Sul (17,7\%) e Bahia (16,2\%). Contudo, em termos de valor, apenas São Paulo e a Bahia detinham maiores transações bancárias do que o Distrito Federal (34,6\% e 19,3\% versus 10,0\%). Desse modo, as instituições bancárias nacionais e estrangeiras concentravam os maiores empréstimos hipotecários do Brasil, realizados em poucas capitais e cidades do interior de maior dinamismo econômico. Ademais, o grande volume de transações efetuou-se por particulares.

Uma medida da importância do mercado hipotecário no Brasil pode ser calculada por meio da participação dos valores transacionados em relação ao PIB, como observado no Gráfico 3. ${ }^{30}$ Já em 1909 as hipotecas representaram pouco mais de três pontos porcentuais do produto daquele momento $(3,3 \%){ }^{31}$ Tal parcela cresceu até 1914 , quando atingiu quase sete pontos $(6,6 \%) .{ }^{32}$ Durante a Primeira Grande Guerra ocorreu uma expressiva retração do crédito hipotecário, diminuindo a sua participação a dois pontos em 1918 (2,1\%). ${ }^{33}$ Desconsiderando os anos de 1921 e 1922, verificamos uma recuperação da importância do crédito depois da Guerra até a segunda metade da década de 1920, chegando a quase seis pontos porcentuais em 1930. ${ }^{34}$

enquanto o Anuário informa 144, levantamos apenas 12. Assim, ao que tudo indica o nosso critério de banco foi muito mais seletivo do que o informado nessa seção, talvez incluindo negociantes e companhias.

${ }^{30}$ Utilizamos os informes de PIB e deflator implícito de Claudio Haddad (1978).

${ }^{31}$ O estoque de moeda (M1) representou um quinto do PIB em 1909 e os depósitos a prazo em instituições bancárias somaram 2,8\% do PIB nesse ano. Aldo Musacchio estimou em cerca de 4,6\% do PNB para 1909 os empréstimos hipotecários dos bancos (2009, p. 64). Devemos ressaltar que tais informações são o estoque dos financiamentos e que os nossos dados são o fluxo de novas hipotecas.

32 Os depósitos a prazo dos bancos também cresceram, alcançando 5,1\% do PIB em 1914.

33 A retração dos depósitos mostrou muito mais reduzida nos primeiros anos da Guerra, posteriormente os montantes depositaram aumentaram em 1918 em função da expansão monetária, chegando a 5,6\% do PIB. Ao contrário, as hipotecas retraíram-se durante a Guerra de forma continuada, mostrando um comportamento distinto das variáveis monetárias e dos depósitos.

34 Nos anos de 1921 e 1922, ocorreram transações muito vultosas na capital da República, porém não conseguimos descobrir o motivo. 


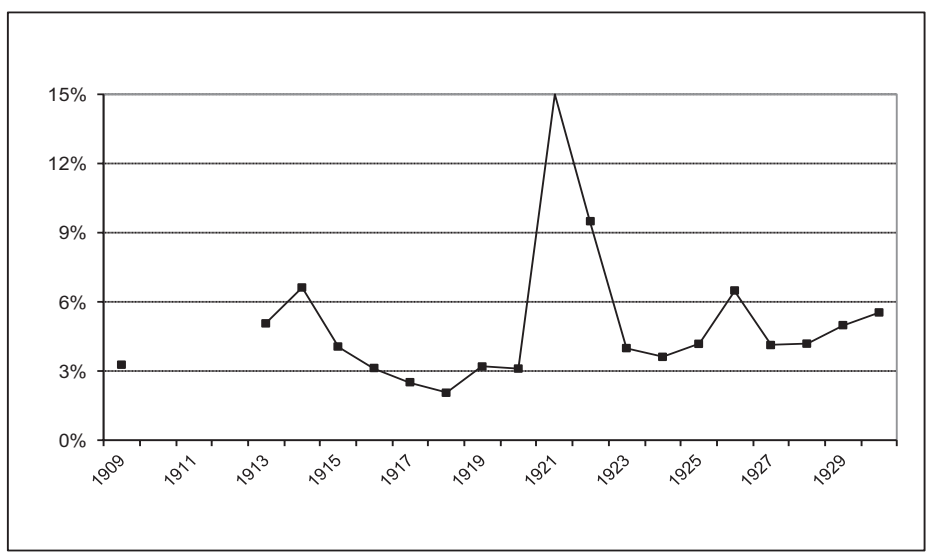

Gráfico 3 - Valor das Hipotecas sobre o PIB brasileiro (em \% do PIB, 1909-1930)

A participação das novas hipotecas no PIB oscilou, em geral, entre 3\% e 7\% durante o período 1909-1934. Isto se refere ao fluxo de hipotecas e não ao estoque em vigor. Podemos realizar uma tentativa de estimar o estoque de hipotecas em relação ao produto. Para isto é necessário calcular o prazo desses empréstimos. Se assumirmos de forma conservadora um prazo médio de 2 anos, a participação do estoque de hipotecas deve se situar de $6 \%$ a $14 \% .{ }^{35}$ Tal resultado assemelha-se aos estimados por Goldsmith e Musacchio para os títulos e ações. ${ }^{36}$

Ainda podemos considerar em separado o Estado de São Paulo no Gráfico 4. Novamente os movimentos das duas informações revelaram-se semelhantes ao longo do tempo considerado, principalmente nesse espaço. ${ }^{37} \mathrm{Em} \mathrm{1909}$, as hipotecas paulistas totalizaram mais de quatro décimos do conjunto brasileiro, tanto em número quanto em valor. A partir de meados dos anos 1920, a participação paulista cresceu para mais da metade do total do país, chegando a $51,7 \%$ da primeira variável e 58,5\% da segunda em 1930. Destarte, evidenciou-se a importância da economia paulista na primeira República, elevando

\footnotetext{
35 Considerando as hipotecas paulistanas de 1909 a 1914, o prazo médio foi de 3,1 anos e a mediana 3. Além de supormos um prazo médio menor, normalmente as hipotecas de maior valor apresentam prazos maiores, que deveria elevar a estimativa do estoque de hipotecas.

36 Podemos realizar outra comparação com relação ao estoque da dívida interna do governo federal, que oscilou entre 8\% e 16\% de 1909 a 1930.

37 A correlação entre número e valor foi muito expressiva $(0,840)$.
} 
seus créditos e sua participação relativa nas hipotecas brasileiras ao longo do período em tela.

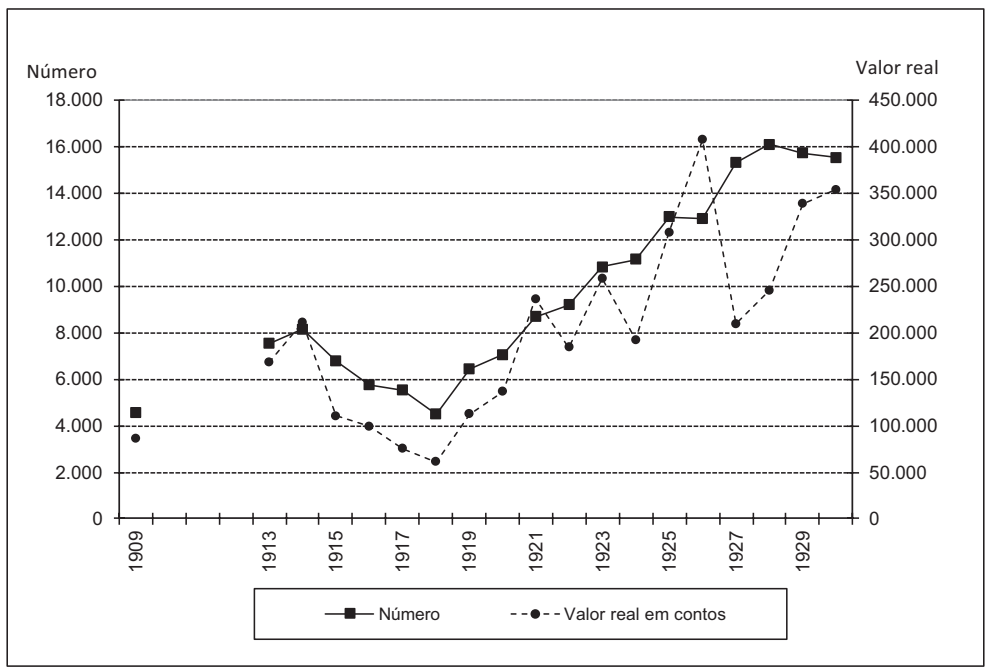

Gráfico 4 - Número e valor real das hipotecas do Estado de São Paulo (19091930)

Em São Paulo, a participação do ambiente rural e urbano alterou-se expressivamente ao longo das primeiras décadas do século XX. Em 1909, o primeiro representou cerca de um terço do número total de hipotecas $(33,3 \%)$ e pouco mais da metade dos valores transacionados (57,1\%). Em 1929, as participações reduziram-se para 26,7\% do número e 38,9\% dos valores, demonstrando a importância crescente do urbano no Estado. Esta mudança revelou-se bastante expressiva durante os anos vinte. Por outro lado, o sistema bancário também abarcava uma parte menor do mercado hipotecário paulista em comparação com o restante do país, principalmente o Distrito Federal. No primeiro ano considerado, os bancos perfaziam tão-somente $4,6 \%$ dos empréstimos em número e $12,8 \%$ dos valores. Estas instituições revelaram menos importantes em São Paulo do que no restante do país. $^{38}$

${ }^{38}$ Os particulares detinham grande penetração nos empréstimos hipotecários, mas não se restringiam a estes, como penhores etc. Uma estimativa precária da totalidade dos empréstimos pode ser obtida pela arrecadação do imposto sobre capitalistas, sujeito à alíquota de 0,5\% sobre o capital particular empregado em empréstimos ( $c f$. Decreto Estadual 1.251 de 12 de novembro de 1904). Para o ano de 1905, cadastraram 1.352 pessoas na cidade para pa- 
O município de São Paulo centralizou de modo marcante as transações do Estado. Em 1909, a capital paulista totalizou quase duas mil hipotecas, representando pouco mais de quatro décimos do total das hipotecas paulistas $(42,1 \%)$ e cerca de um quarto dos valores transacionados $(24,5 \%)$. A quase totalidade das transações paulistanas referiu-se a imóveis urbanos, tanto em valor quanto em número, porém mantendo o padrão dos menores valores das hipotecas urbanas em relação às rurais. Os bancos representaram 7,5\% do número e 15,9\% dos valores das hipotecas paulistas em 1909, assumindo um papel um pouco maior do que no interior. ${ }^{39} \mathrm{Na}$ próxima seção, ao analisarmos os dados mais desagregados das hipotecas do município de São Paulo poderemos comparar estes resultados disponíveis na literatura. Destarte, ao avaliarmos as informações coletadas acerca do mercado hipotecário em São Paulo poderemos notar as consequências dessas políticas econômicas e legislações descritas anteriormente, particularmente as do último quartel do século XIX e início do XX.

\section{Crédito Hipotecário Paulistano}

A cidade de São Paulo apresentou um crescimento extraordinário no período em estudo, constituindo o centro econômico de um Estado bastante dinâmico. A expansão cafeeira no interior do Estado e a diversificação das atividades transformaram São Paulo na principal economia do país no início do século XX. A cidade assumiu grande importância no fluxo de comércio em razão do entroncamento das estradas, mesmo antes do avanço ferroviário ou cafeeiro. ${ }^{40}$ Desse modo, São Paulo destacou-se nas funções comerciais, administrativas e, como já vimos, financeiras. Os serviços públicos e privados expandiram-se vigorosamente nesse momento. Por fim, a expansão industrial foi muito rápida, tornando o principal centro do país nas primeiras décadas do século XX.

gar o imposto, porém alguns mantinham dois números de arrecadação (cf. Correio Paulistano de 4 de abril de 1905, p. 4). Em 1909, a arrecadação foi de 490 contos no Estado, assim a base de cálculo para o imposto chegou a quase cem mil contos de réis, muito acima dos 66 mil contos realizados por particulares em hipotecas. Ao que tudo indica o mercado hipotecário era o mais importante, mas não o único de atuação dos capitalistas.

39 Se em 1909, a participação das hipotecas paulistanas chegou a 18,4\% em número e 11,6\% em valor do país, em 1930, elas representaram cerca de um quinto, tanto em número como em valor. Assim, houve um aumento da representatividade paulistana no conjunto brasileiro, principalmente com relação aos valores no período.

40 Ver Caio Prado Jr. (1983). 
A população cresceu, expressivamente, de pouco mais de trinta mil habitantes em 1872 para mais de seiscentos mil em 1920, incrementada pela chegada de milhares de imigrantes estrangeiros. ${ }^{41} \mathrm{~A}$ expansão da cidade demandou recursos para o crescimento imobiliário urbano. O boom também atingiu a construção civil, que se apoiou no crédito, em especial no hipotecário. Desse modo, a grande maioria das transações hipotecárias referiu-se a imóveis urbanos residenciais, industriais e comerciais.

No período em análise nesta pesquisa até o final da década de 1920, observamos um crescimento extraordinário do número de hipotecas, conforme o Gráfico $5 .{ }^{42}$ Nos primeiros anos, poucos negócios foram realizados, porém aos poucos as transações aumentaram, atingindo uma centena em 1878 e mais de quinhentos casos no último ano do Império. Pouco mais tarde já alcançou mais de mil transações em 1891. Por outro lado, uma retração desse mercado mais expressiva ocorreu a partir de 1898, decorrente possivelmente das políticas restritivas de Joaquim Murtinho e ocorrendo o menor registro em 1902 num total de menos de novecentos. Tal retração mostrou-se menos severa do que a do Distrito Federal. Após 1902 houve uma recuperação do número de hipotecas, chegando em 1913 a quase de quatro mil. Como esperado, uma nova redução ocorreu durante o conflito da $1^{\text {a }}$ Grande Guerra, chegando a pouco mais de duas mil hipotecas em 1918. ${ }^{43}$ Depois do término da guerra a recuperação mostrou-

${ }^{41}$ Utilizamos as informações da Fundação Seade para a mesma unidade territorial de 1872.

${ }^{42}$ Os dados usados nesta seção foram coletados no Arquivo Público do Estado de São Paulo na documentação do $1^{\circ}$ Cartório de Imóveis referente à série dos livros 2, desde o primeiro livro em 1865 até 1920 . As hipotecas do $1^{\circ}$ Cartório representam a totalidade das transações na capital paulista até o início do século XX. Se compararmos o total do registro nesse cartório com as informações da cidade no Anuário Estatístico do Brasil, verificamos números muito semelhantes para o ano de 1909: 1917 em nosso banco de dados e 1919 no Anuário. A partir de 1912 utilizamos, apenas no Gráfico 5 e 6, as informações mais agregadas das escrituras públicas de hipotecas da capital paulistana publicada nos Anuários Estatísticos de São Paulo, pois se referem à totalidade dos tabelionatos. Quando comparamos os dados das hipotecas registradas no primeiro cartório e as das escrituradas para os anos de 1912 a 1920 verificamos uma subestimação dos registros pelo $1^{\circ}$ Cartório de pouco mais de dez mil hipotecas, em decorrência da existência de outros oficiais nessa época. Ressaltamos que o registro normalmente decorre de uma escritura, como aponta a existência de correlação das duas informações entre 1912 e 1920, especialmente com uma defasagem para o registro $(0,80$ para número e 0,60 para valor). Por fim, utilizamos as informações de inflação no período 1865 a 1869 de Raymond W. Goldsmith (1986, p. 30-31), 1870-1913 de Catão (1992) e 1914-1928 de Haddad (1978). O total de informações analisadas nos Gráficos 5 e 6 atingiu a pouco mais de cem mil hipotecas, como constam do apêndice estatístico ao final do artigo.

${ }^{43}$ Outra informação das escrituras públicas relevante para a nossa discussão consiste nas quitações de empréstimos. Embora não se refiram apenas a hipotecas, compreendendo também os penhores, há uma grande preponderância das hipotecas entre as quitações. Quando ocorre um aumento das concessões de novas hipotecas as quitações demoram um pouco a responder 
se acelerada, bastante superior ao atingido pouco antes do conflito. Assim, se comparado ao verificado na praça carioca ou mesmo no restante do país, como vimos anteriormente, o ritmo de crescimento mostrou-se bastante superior na praça paulistana, acompanhado o próprio dinamismo do município. ${ }^{44}$

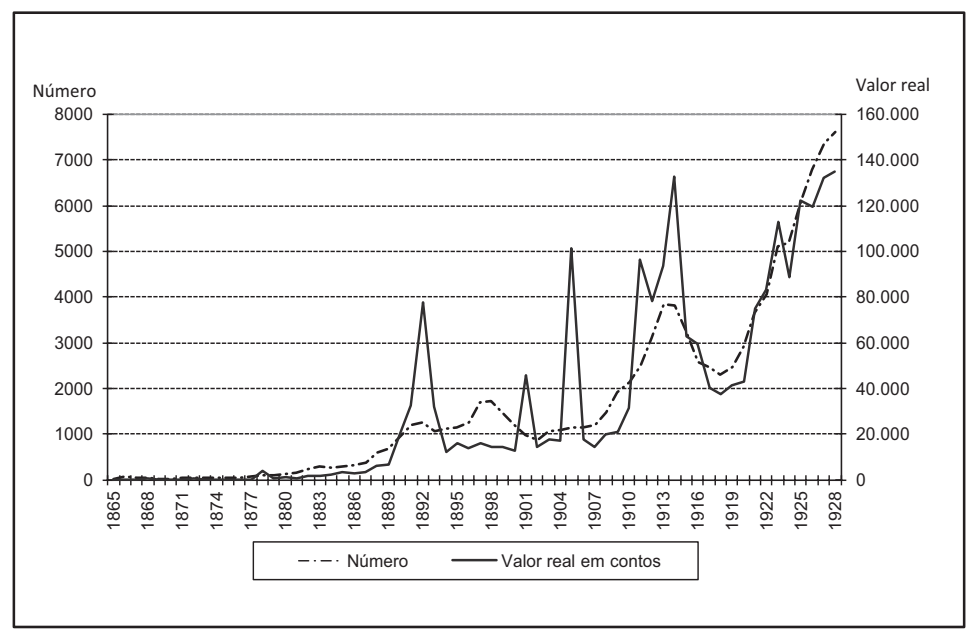

Gráfico 5 - Número e valor real das hipotecas (São Paulo, 1865-1928)

O valor real também apresentou uma tendência crescente ao longo do período, de modo muito assemelhado ao do número. ${ }^{45}$ No início, os valores oscilaram ao redor de uma centena de contos de réis, porém já no início da década de 1880 chegaram a mais de mil contos. Durante o Encilhamento, os valores atingiram mais de vinte mil contos, posteriormente se manteve em patamar pouco menor do que este no final do século XIX e início do XX, à exceção de alguns

a esse crescimento. De outro lado, durante a guerra e mesmo logo após o final do conflito, as pessoas quitaram muito mais dívidas do que realizaram novas hipotecas. Na década de 1920, houve um crescimento das novas hipotecas, acompanhado de forma defasada pelas quitações. De toda sorte, os pagamentos dos empréstimos pareceram-nos bastante elevados. Se houve a escrituração de pouco mais de setenta mil hipotecas entre 1912 e 1928 na capital paulista, quase 65 mil foram quitadas em idêntico período $(89,2 \%)$.

44 Esta tendência também foi observada no caso de Juiz de Fora analisado por Anderson Pires e Rita Almico (2008). A partir dos dados cedidos pelo primeiro autor foi possível calcular a correlação entre as duas séries. Verificamos uma correlação estatisticamente significativa de número e valor das hipotecas para Juiz de Fora e São Paulo entre 1868 e 1928, atingindo 0,345 e 0,469 respectivamente. Agradecemos a Anderson Pires a disponibilização dos seus dados.

${ }^{45}$ A correlação de número e valor real foi muito elevada de 0,905. 
casos excepcionais. Os anos anteriores à Grande Guerra foram bastante favoráveis ao mercado de hipotecas paulistano, apresentando as transações quantias médias elevadas. Em 1914, os valores alcançaram pouco mais de cento e trinta mil contos, porém o conflito provocou uma retração mais forte do valor em comparação com o número, atingindo um valor inferior a quarenta mil contos. A recuperação foi rápida durante os anos vinte, alcançando o patamar anterior à guerra na segunda metade da década. Tal resultado salientou uma diminuição do valor médio das hipotecas no período do conflito, que se recuperou pouco posteriormente. A série de valor real apresentou uma maior ocorrência de ápices mais pronunciados do que a de número. Tal fato decorre da existência de casos de valores excepcionais, que muitas vezes abarcam patrimônio além dos existentes no próprio município, como as ferrovias que detinham trilhos e estações muito além do município.

Além de eliminarmos o efeito dos aumentos do nível de preços, podemos calcular o número e o valor constante em termos per capita. ${ }^{46}$ O Gráfico 6 fornece estas informações para o período em estudo. A dinâmica crescente do mercado mantém-se nesta análise, em especial ao final da década de 1870 e na década seguinte. O apogeu passou a ocorrer no Encilhamento, pois há uma retração posterior, no início do século XX. Contudo, a principal mudança consiste na tendência de recuperação nas primeiras décadas do século XX, que ocorre de forma bastante atenuada e restrita aos anos anteriores a Primeira Grande Guerra. Esse último conflito provocou a redução ainda maior dos indicadores. Depois do conflito, a recuperação revelou-se consistente tanto em número como em valor, porém até 1928 ainda não se atingiram os patamares do momento anterior a Grande Guerra. Assim, o dinamismo do mercado hipotecário deve ser entendido a luz do grande fluxo imigratório para a cidade.

${ }^{46}$ Utilizamos as informações censitárias de 1872, 1890, 1900, 1920 e 1940 e estimamos a população nos períodos intermediários por meio de uma interpolação da taxa média geométrica. Assim, o incremento demográfico da imigração estrangeira revela-se mais distribuído ao longo dos períodos. 


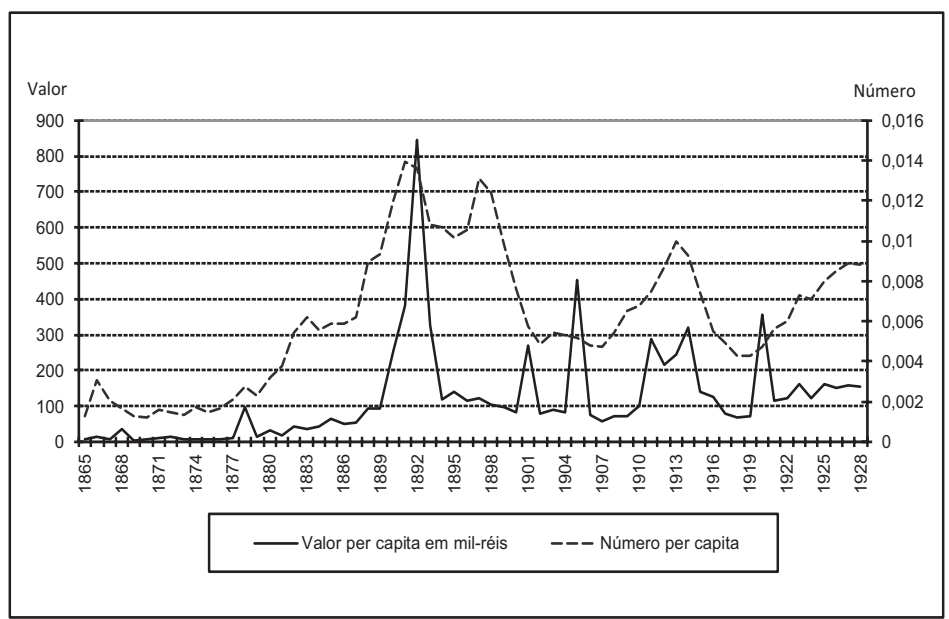

Gráfico 6 - Número e Valor real per capita (São Paulo, 1865-1928)

Como já notado nos gráficos anteriores, há casos excepcionais que precisam ser pelo menos mencionados. Selecionamos quatro casos mais destacados para salientar a excepcionalidade. $\mathrm{O}$ primeiro caso extraordinário foi realizado pelo Deutsche Brasilianische Bank, que efetuou apenas uma transação em 1878. Ele emprestou à Companhia Sorocabana 2.288 contos de réis, hipotecando a estrada de ferro da Companhia Sorocabana com todo o seu material, trem rodante, oficinas, estações, utensílios e tudo quanto a ela pertence. Outro caso ocorreu de um lançamento de títulos preferenciais, realizado para a Companhia Paulista de Vias Férreas e Fluviais, em 1892, intermediado pelo The British Bank of South América e English Bank of Rio de Janeiro. ${ }^{47}$ Tal operação atingiu 2.870 mil libras esterlinas e representou pouco mais de um terço dos valores totais hipotecados. Foi garantida pelas linhas da estrada de ferro e de navegação fluvial que já pertenciam à companhia devedora antes da negociação feita, com todos os seus materiais e edifícios e estradas em diversas comarcas. As condições do empréstimo mostraram-se muito superiores ao comumente efetuado na praça paulistana, em virtude de uma taxa de juros cobrada de $5 \%$ ao ano e um prazo de 42 anos. O terceiro caso semelhante a esse ocorreu em 1901, entre a companhia de eletricidade e transporte The São Paulo Tramway Light and Power, financiada

\footnotetext{
${ }^{47}$ As atividades bancárias desta instituição começaram em 1862, como Brazilian and Portugue se Bank, e, em 1866, se alteraram para English Bank of Rio de Janeiro. Em 1891, o nome do banco foi alterado para conduzir as operações no Brasil e na Argentina.
} 
pelo banco National Trust Company Limited, ambos oriundos do Canadá. A empresa iniciou suas atividades em 1899, com a construção da Usina Hidrelétrica Parnaíba. Os imóveis hipotecados referemse principalmente a terrenos e equipamentos relacionados à geração e à distribuição de energia elétrica. $\mathrm{O}$ total do empréstimo alcançou seis milhões de dólares canadenses, com vencimento em $1^{\circ}$ de junho de 1929 , a uma taxa de juros de $5 \%$ ao ano. ${ }^{48}$

A hipoteca de maior valor no período foi da Estrada de Ferro União Sorocabana e Ituana de propriedade do governo do Estado de São Paulo, com extensão de $914,8 \mathrm{Km}$, compreendendo as linhas, estações, dependências, depósitos, casas, oficinas, armazéns e material fixo e rodante. ${ }^{49}$ A escritura foi passada em 6 de fevereiro de 1905, totalizando um valor de 3,8 milhões de libras, num prazo de 40 anos e juros de 5\% ao ano. Os credores foram os bancos Dresdner Bank de Berlim e Banque de Paris et des Pays-Bas. Mesmo se desconsiderarmos estes quatro casos excepcionais não haverá modificação da tendência crescente do valor real no período, especialmente na década de 1890 e na década anterior a primeira Grande Guerra. Ademais, devemos salientar que a legislação daquele momento permitia o estabelecimento de contratos em moeda estrangeira. Os bancos estrangeiros e também pessoas residentes no exterior firmaram hipotecas em libras esterlinas, marcos alemães, francos franceses e liras italianas. ${ }^{50}$

A partir desse quadro mais geral das hipotecas da capital paulistana, passamos a nos concentrar nas registradas no primeiro cartório no período entre 1865 e 1920, para as quais dispomos dos dados individuais de cada hipoteca. ${ }^{51}$ Nesse banco de dados abarcamos o

${ }^{48}$ Há mais uma hipoteca da Light em 1911 no valor de 10 milhões de dólares canadenses, sendo credor não apenas o National Bank, mas também British Empire Trust Company.

${ }^{49}$ A referida hipoteca incluiu também a navegação fluvial dos rios Piracicaba e Tietê, abarcando cinco vapores de ferro e sete lanchas grandes de ferro.

${ }^{50} \mathrm{Em}$ todo período, verificamos a presença de pouco mais de duzentas hipotecas em moedas estrangeiras, dentre as quais três quartos por meio de instituições bancárias estrangeiras. Em moeda francesa, verificamos a maior parte do conjunto, totalizando 157 transações, especialmente por meio de bancos (86,6\% do total) e nos anos anteriores a Primeira Grande Guerra. Das 35 hipotecas em libras esterlinas também pouco mais de três quartos referiram-se a credores bancários. De outro lado, as transações em marcos e liras foram realizadas por pessoas, alcançando 18 e 7 casos respectivamente.

${ }^{51}$ Não verificamos uma presença significativa do tabelião do cartório na intermediação dos empréstimos como verificado por Hoffman, Postel-Vinay e Rosenthal (2000) para os notários de Paris. A principal indicação desse papel foram alguns anúncios publicados no Estado de São Paulo no início do século XX: "Empréstimos a prazos longos: No registro hipotecário nesta capital, Travessa da Sé n. 6, sobrado, informar-se sobre quem se encarrega de levantar 
registro de quase cinquenta mil hipotecas, sendo a totalidade das existentes até a primeira década do século XX. Iniciamos a análise das condições dos empréstimos, que também devem ser consideradas em relação ao contexto da época. O prazo médio dos empréstimos cresceu significativamente no período numa tendência bastante regular, passando de pouco mais de um ano na década de 1860 para pouco mais de três anos nos primeiros anos da década de 1910, como pode ser observado no Gráfico $7 .{ }^{52} \mathrm{~A}$ melhora dos termos dos financiamentos decorreu do afrouxamento da política monetária, mas provavelmente das mudanças institucionais ocorridas e a maior presença bancária. As flutuações impactaram menos nessa série do que as anteriores. Utilizamos o coeficiente de variação como uma medida de desigualdade dos prazos. Observamos uma oscilação do indicador, sem uma tendência clara no período. Além disto, não se alargou a diferença de prazos entre os créditos de maior valor em relação aos de menor montante.

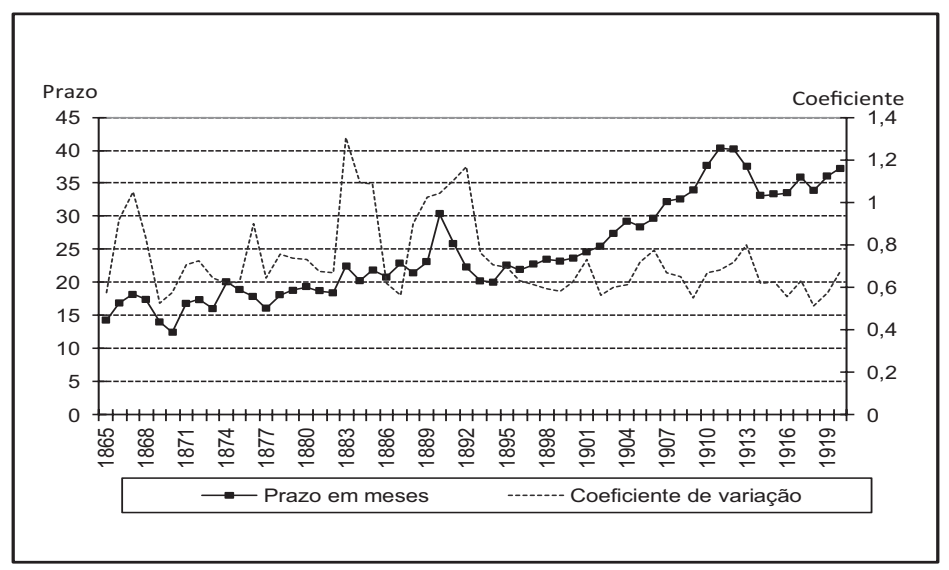

Gráfico 7 - Prazo médio e coeficiente de variação (São Paulo, 1865-1920)

As taxas de juros foram consideradas a partir da exclusão do efeito da inflação, que foi mais elevada na última década do século XIX, como visto no Gráfico $8 .^{53}$ Os juros reais mantiveram-se durante o

empréstimos a longos prazos, mediante garantia hipotecária de prédios bem situados nesta cidade ou na de Santos, tomando a si, caso os interessados o queiram, o pronto preparo dos documentos." (17 de dezembro de 1901, p. 3).

52 Se compararmos com os dados de Juiz de Fora notamos uma correlação dos prazos estatisticamente significativa entre 1865 e $1920(0,373)$.

${ }^{53}$ Novamente, quando comparamos os juros nominais de São Paulo e Juiz de Fora verificamos uma correlação bastante elevada e significativa entre 1865 e $1920(0,643)$. Tal resultado 
Império patamares expressivos, ao redor de $10 \%$ ao ano ou mais. A política republicana do Encilhamento e as consequências da Primeira Guerra produziram uma inflação expressiva, chegando a dois dígitos e produzindo distorções no mercado. Os juros reais reduziram-se e tornaram-se mais instáveis, chegando, em alguns desses anos, a uma taxa negativa. A política de estabilização na passagem para o XX elevou fortemente as taxas, que atingiram valores muito expressivos. Posteriormente, nas primeiras décadas do século XX houve uma tendência de redução das taxas. O coeficiente de variação dos juros diminuiu ligeiramente, mostrando uma menor divergência entre as taxas do que no caso do prazo. Destarte, os juros reais mostraram-se mais instáveis durante o período republicano.

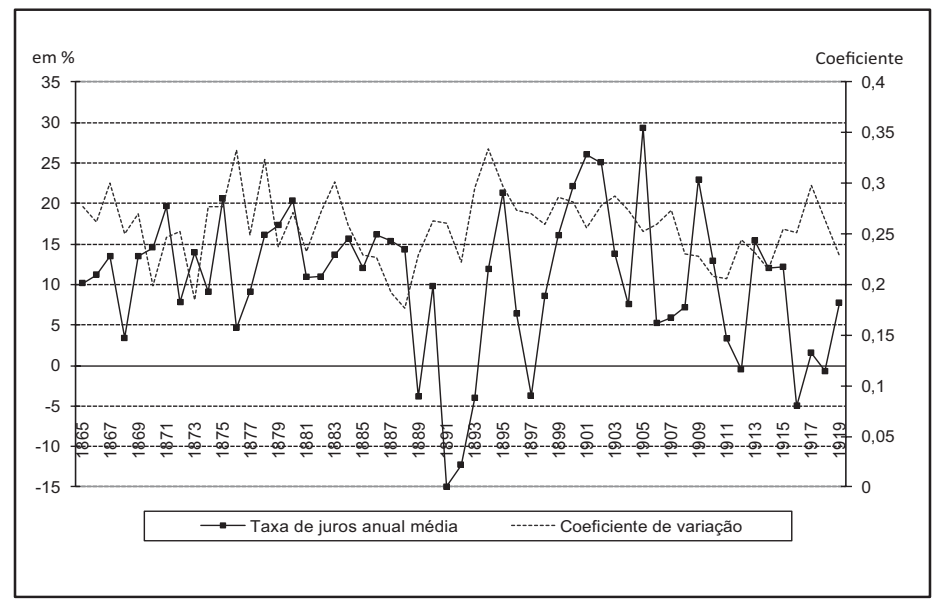

Gráfico 8 - Taxa de juros reais e coeficiente de variação (São Paulo, 1865-1920)

Outra análise interessante refere-se ao perfil dos devedores e credores. A documentação utilizada informa o nome, moradia e atividade deles, além da localização e características do imóvel dado em garantia da hipoteca. Como esperado, a quase totalidade dos devedores residia na comarca de São Paulo (96,0\%). Apenas 3,2\% apresentavam residência no interior de São Paulo, $0,3 \%$ no Rio de Janeiro, $0,3 \%$ no exterior e $0,2 \%$ no restante do Brasil. Com relação aos credores, a situação mostrou-se pouco distinta, detendo a capital a moradia de cerca de nove décimos do total $(89,7 \%)$. De outro lado, a presen-

apontou para uma maior arbitragem em termos das taxas de juros do que nas demais variáveis cotejadas. 
ça dos moradores do interior de São Paulo e do exterior foi mais expressiva, atingindo $6,4 \%$ e $3,1 \%$ respectivamente. ${ }^{54}$ Em termos dos valores emprestados, os credores da capital do Estado e interior representaram $59,0 \%$ e $6,7 \%$, respectivamente. De outro lado, os do Rio de Janeiro e exterior perfizeram $13,7 \%$ e $18,8 \%$, considerando os quatro casos destacados anteriormente. ${ }^{55}$ Este último número destacou-se em virtude da existência de relações empresariais com outros países, mas também pessoais e familiares especialmente com a Europa.

A partir das informações das características dos imóveis dados em garantia pelos devedores podemos tentar entender o destino dos recursos emprestados. ${ }^{56}$ Agrupamos os imóveis segundo categorias mais amplas. A grande maioria dos imóveis eram casas e terrenos, totalizando mais de nove décimos das hipotecas (93,5\%). Ademais, os sítios e chácaras perfaziam 3,8\%. Tais resultados salientaram a importância do crédito imobiliário nas hipotecas. Ainda verificamos a presença significativa de imóveis industriais $(1,4 \%)$, mais significativos do que os comerciais $(0,8 \%)$.

Para o conjunto do período, as atividades dos credores e devedores concentraram-se fortemente na figura de proprietários, representando pouco mais da metade dos primeiros $(55,3 \%)$ e cerca de nove décimos dos segundos $(91,3 \%)$. Tal categoria pouco esclarece a respeito da ocupação dos credores e devedores, informando apenas a propriedade de imóveis que no caso de transações hipotecárias era esperada. ${ }^{57}$ De outro lado, a importância relativa dos proprietários na

\footnotetext{
${ }^{54}$ Rio de Janeiro perfez $0,6 \%$ dos credores e o restante do Brasil 0,3\%.

$55 \mathrm{O}$ restante do Brasil representou 1,8\% dos valores transacionados.

${ }^{56}$ Os empréstimos relacionavam-se principalmente a expansão imobiliária da cidade, que apresentou um boom na última década de 1890. A hipoteca tornou-se um instrumento importante para o financiamento à aquisição de residências e imóveis em geral. Para alguns casos dispomos da informação da data de compra do imóvel. Dentre estes, chegamos a observar as duas transações em dias muito próximos, salientando a origem dos recursos para a aquisição. Ilustrativamente, notamos um caso da compra de dois prédios em 25/1/1905 e o registro da hipoteca no dia seguinte. Embora não tenhamos regularmente estas informações da forma de aquisição do imóvel, elas reforçam a associação entre a transação de compra e a da hipoteca como financiamento em São Paulo. Para o período de 1912 a 1928, por meio das escrituras de compra e hipoteca, verificamos que as segundas representaram 46,4\% do número e 82,6\% dos valores transacionados. De outro lado, a correlação entre os valores das escrituras e os das hipotecas foi muito elevada no período disponível das informações $(0,93)$. Assim, o mercado hipotecário manteve uma forte associação ao imobiliário na cidade de São Paulo nessa época.

57 Uma mesma pessoa apresentava ocupações diversas entre os credores, como de proprietário e outras. Realizamos uma padronização para estes casos, imputando as outras em substituição a de proprietário. Este procedimento reduziu um pouco a incidência dos proprietários entre eles.
} 
soma dos valores transacionados revelou-se menor do que no total de hipotecas, representando $19,5 \%$ dos credores e $44,4 \%$ dos devedores. A segunda ocupação para os credores mais comum foi de capitalistas $(24,8 \%)$. Eles ainda mantinham as seguintes atividades: negociante $(6,5 \%)$, advogado $(1,7 \%)$, instituição bancária $(2,6 \%)$, caixa de aposentadoria $(2,3 \%)$, profissional liberal $(1,5 \%)$, companhia $(1,1 \%)$ etc.58 Os devedores não proprietários compreendiam um conjunto mais disperso de atividades, como principalmente negociante $(3,3 \%)$, lavoura $(1,3 \%)$, advocacia $(0,6 \%)$, profissional liberal $(0,7 \%)$, industrial $(0,5 \%)$, companhia $(0,5 \%)$ e artista $(0,5 \%) .{ }^{59}$

\section{Bancos e Capitalistas nas Hipotecas}

Como vimos no conjunto do país, o mercado hipotecário paulistano da época operava na grande maioria das vezes por meio de particulares $(93,0 \%)$, que são pessoas físicas. A presença de instituições formais de crédito mostrava-se limitada. No período 1865-1920, os bancos realizaram apenas $2,6 \%$ das hipotecas, mas compreenderam $41,5 \%$ dos valores transacionados. Como visto no Gráfico 9, apesar das flutuações, houve uma tendência crescente da participação relativa dos bancos, principalmente nos valores. Além dos quatro casos extraordinários relatados anteriormente, os bancos passaram a atuar de modo mais expressivo no mercado hipotecário a partir de 1883, quando do início das operações do Banco de Crédito Real de São Paulo. ${ }^{60}$ Até aquele momento a Caixa Filial do Banco do Brasil realizou apenas uma dezena de empréstimos, enquanto instituição priva-

${ }^{58}$ Dois casos muito distintos dos anteriores devem ser destacados. Os credores detentores de debêntures de companhias entre 1900 e 1919, em geral sociedades anônimas de serviços públicos, industriais e imobiliárias. Neste caso, o instrumento da hipoteca consistiu numa possibilidade de melhorar as garantias para os compradores desses títulos. As 33 hipotecas de debêntures perfizeram $6,2 \%$ dos valores transacionados em todo período. Assim, o grande número de "futuros debenturistas" e as quantias bastante elevadas das transações ressaltam o caráter muito diferente dos empréstimos mais comuns. Por fim, as caixas de aposentadoria também elevaram a sua participação no início do século XX, representando um conjunto bastante expressivo de transações - pouco mais de dois por cento do número e do valor.

${ }^{59}$ As companhias, empresas de serviços públicos e as indústrias contrataram 10,1\%, 14,6\% e $5,0 \%$ dos valores emprestados.

${ }^{60}$ O Banco de Crédito Real de São Paulo funcionará até o início do século XX. Em 1903, os imóveis hipotecados pelo banco somaram 53,5 mil contos de réis, conforme o The Brazilian Review de 8 de dezembro (Wileman, 1903, v. 6, n. 49, p. 698 e, ver também, 1904, v. 7, n. 16, p. 229). Por fim, um banco estrangeiro efetuou um grande financiamento a uma ferrovia em 1878, como observado no gráfico. 
da. O Encilhamento favoreceu a expansão do crédito bancário nacional, mas se retraiu no ajuste ao final do século XIX. Posteriormente, os bancos ganharam uma parcela substancial do mercado no início do século XX, especialmente os estrangeiros. ${ }^{61}$ Por fim, a Primeira Grande Guerra revelou um aumento relativo das transações bancárias, porém representando uma participação um pouco menor no valor total das hipotecas. Embora as hipotecas não fosse o principal negócio dos bancos, eles expandiram, em número, suas operações hipotecárias em maior proporção do que os demais agentes nesse mercado na década de $1910 .^{62}$

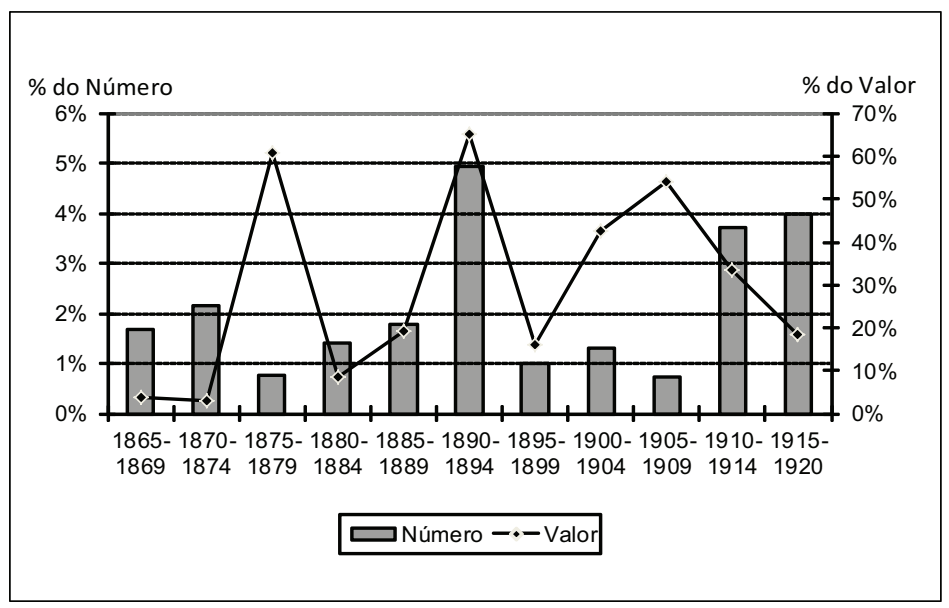

Gráfico 9 - Participação dos bancos no número e valor total (São Paulo, 1865 1920)

${ }^{61}$ Os bancos estrangeiros perfizeram $38,1 \%$ das hipotecas bancárias em todo o período. Entretanto, no período de 1909 a 1920, a participação desses bancos elevou-se a 57,8\%. Um dos mais atuantes foi o Crédit Foncier du Brésil et L'Amerique du Sud com sede em Paris, totalizando 281 hipotecas a partir de 1911. Para uma discussão específica sobre os bancos em São Paulo ao final do século XIX ver Renato Marcondes \& Anne Hanley (2010).

${ }^{62}$ Os registros das hipotecas nos balanços contábeis dos bancos começaram a ocorrer a partir do decreto 14.728 de 16 de março de 1921, que instalou a Inspetoria Geral de Bancos responsável pela fiscalização bancária. O decreto também determinava um formato na publicação dos balancetes, explicitando as hipotecas. Em São Paulo, o primeiro registro ocorreu em fevereiro de 1922, já somando pouco menos de cem mil contos de réis. Tal quantia representou 3,3\% dos ativos dos bancos da capital, compreendendo as agências e filiais do interior (cf. REPARTIRÇÃO DE ESTATÍSTICA E ARQUIVO DO ESTADO, 1929, p. 356). A maior parte das hipotecas foi realizada pelo Banco do Estado de São Paulo, denominado até 1925 como Banco de Crédito Hipotecário e Agrícola do Estado de São Paulo. No caso carioca, o Jornal do Comércio informava a existência de pouco mais de trezentos mil contos em hipotecas nas carteiras dos bancos em 1922, perfazendo 2,6\% do total dos ativos (1929, p. 217-219). 
Salientamos que os bancos nacionais e estrangeiros constituíam-se na sua quase totalidade privados, até mesmo o Banco do Brasil do século XIX. Os bancos públicos foram muito pouco atuantes nesse mercado. A Caixa Econômica de São Paulo realizou seis empréstimos, sendo dois logo depois da sua criação em 1875 e os outros quatro entre 1910 e 1920. O Banco da República foi liquidado em 1905 e transformou-se num novo Banco do Brasil, assumindo o governo federal metade do capital da nova instituição e o controle administrativo. A partir desse ano, a empresa mista realizou apenas duas hipotecas em 1912 e em 1915, salientando a reduzidíssima participação do crédito de caráter mais público federal em São Paulo nessa época. Outra instituição com participação pública foi o Banco de Crédito Hipotecário e Agrícola do Estado de São Paulo, criado em 1909 com capital francês e garantia de lucros do governo estadual. A partir de 1914 o governo estadual assumiu parcela minoritária do capital da instituição (30\% segundo Triner, 2000, p. 168), posteriormente o Estado passou a controlar o banco. Esta instituição efetuou 48 hipotecas, sendo que 21 nos dois anos últimos anos da nossa pesquisa.

Apesar do crescimento no período dos bancos, outro grupo também foi especializado na atividade creditícia, denominados capitalistas. Eles efetuaram um número muito superior de transações, pouco mais de onze mil versus pouco mais de mil dos bancos. Ademais, os capitalistas eram credores de $17,4 \%$ dos valores transacionados. O Gráfico 10 demonstra que mesmo nas primeiras duas décadas do século XX, os capitalistas mantinham-se bastante atuantes, realizando sempre um maior número de negócios hipotecários do que os bancos. Assim, evidencia-se a incipiência do sistema bancário no segmento hipotecário naquele momento, especialmente para os negócios com pessoas físicas. Todavia, a Grande Guerra reduziu mais fortemente a atuação dos capitalistas do que dos bancos, aproximando o número e, como veremos adiante, o perfil dos empréstimos, como veremos abaixo. Estas últimas informações apontam para uma tendência de alteração desse quadro para a década de 1920 . 


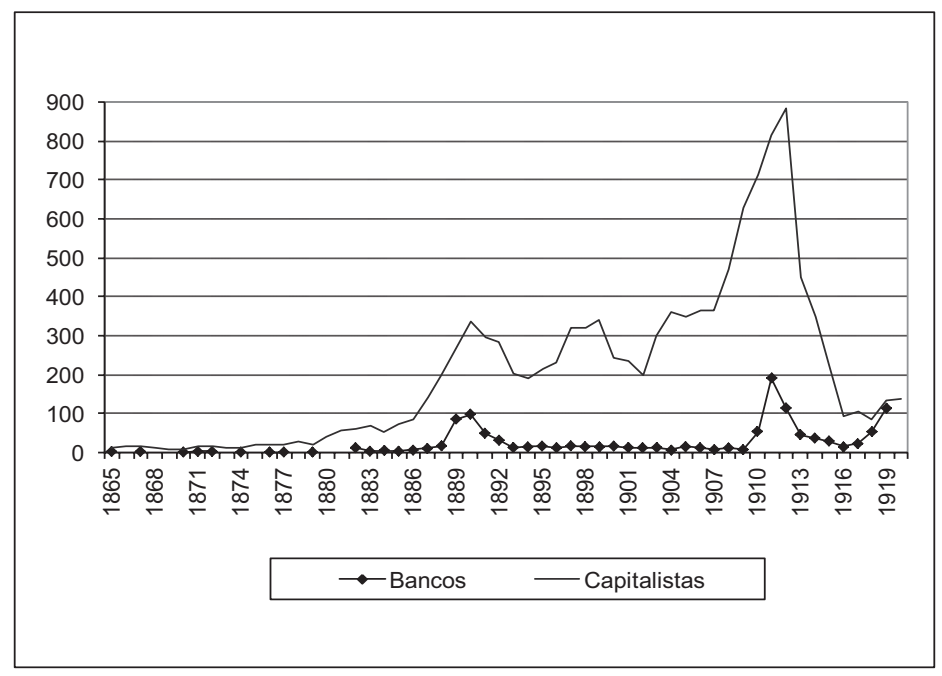

Gráfico 10 - Número de hipotecas dos bancos e capitalistas (São Paulo, 1865 1920)

Os capitalistas não atuavam apenas nesta atividade, pois muitos eram advogados, médicos, farmacêuticos, negociantes, comerciantes, fazendeiros, construtores e até professores. Algumas mulheres também foram denominadas como capitalistas, especialmente viúvas, solteiras e casadas com separação de bens. Os maiores capitalistas realizaram mais transações hipotecárias do que muitos dos principais bancos da época. Muitos efetuaram dezenas e alguns até centenas de hipotecas. ${ }^{63}$ A grande maioria residia na cidade de São Paulo $(86,5 \%)$, porém ainda morava $7,9 \%$ no interior do Estado e 4,9\% no exterior. ${ }^{64}$

63 Alguns exemplos dos capitalistas mais atuantes em termos de número de hipotecas realizadas foram: Antonio Bento de Paiva Azevedo 152 hipotecas, Dr. Antonio Martins de Miranda 176 hipotecas, Antonio Vaz Porto 162 hipotecas, Bernardo Diederichsen 120 hipotecas, Capitão Chrispiniano Augusto Ferreira Lopes 208 hipotecas, Domingos Maurano 131 hipotecas, Francisco de Sampaio Moreira 146 hipotecas, Jacob Kuhn 143 hipotecas, José Antonio Ribeiro Marcondes 196, Manoel Francisco da Silveira 223, Manoel Ramos Paiva 119, Mathias Schreiber 205, Dr. Vicente Ferreira da Silva 197. Destes onze foram chamados a pagar o imposto sobre capitalistas no lançamento de 1910 , que incidia em $0,5 \%$ sobre o valor do capital empregado em empréstimos no ano. O total pago por estas pessoas chegou a pouco mais de 12 contos de réis ( $c f$. CORREIO PAULISTANO, 1910, vários números). Dos dois restantes, Manoel Francisco da Silveira faleceu em 1907 e Mathias Schreiber fez a última hipoteca em 1905, assim provavelmente não estava mais vivo ou atuante em 1910.

${ }^{64}$ Dentre as pouco mais de quinhentas hipotecas de capitalistas estrangeiros, a maioria era da Alemanha (37,3\%), Portugal (22,9\%), Itália (13,8\%) e França $(9,6 \%)$. A Inglaterra detinha apenas três pontos porcentuais desse total. 
Mesmo desconsiderando os quatro casos extremos dos bancos relatados anteriormente na comparação dos dois tipos de credores, verificamos que em termos de valor os bancos transacionaram quantias muito superiores a dos capitalistas. Os primeiros emprestaram em média 188 contos de réis em cada transação enquanto os segundos forneciam em média 14. A soma dos valores transacionados pelos bancos foi de 394 mil contos, enquanto os capitalistas efetuaram negócios de 165 mil contos. ${ }^{65}$

As taxas de juros bancárias nominais revelaram-se, quase sempre, mais reduzidas do que a dos capitalistas entre 1883 e 1920, conforme o Gráfico $11 .{ }^{66}$ No conjunto do período, os juros médios foram de $9,0 \%$ ao ano para as instituições bancárias e de $12,2 \%$ para as pessoas especializadas em emprestar. Ao final do período houve uma tendência de maior aproximação das taxas de juros dos dois ofertantes de crédito, principalmente em função da redução dos juros dos capitalistas. O reduzido número de empréstimos bancários no início elevou a instabilidade das taxas cobradas, porém ao final do período o alargamento das transações dos bancos não permitiu retração dos juros como dos capitalistas.

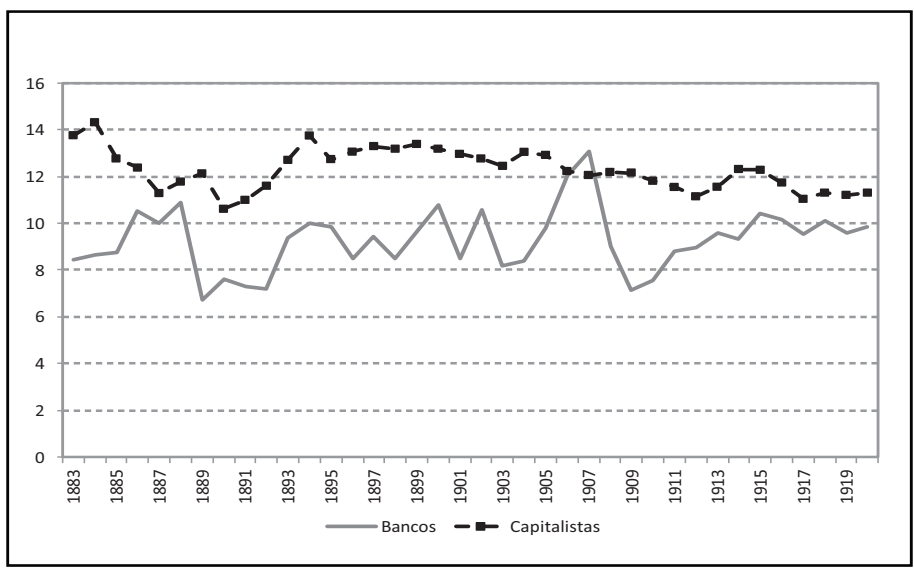

Gráfico 11 - Taxas de juros anual média dos bancos e dos capitalistas (São Paulo, 1883-1920)

${ }^{65}$ Como ocorria com os bancos que realizavam financiamentos não apenas por meio de hipotecas, os capitalistas também realizavam outras transações de empréstimos sem garantia real. O valor tributado para o cálculo do imposto de 1910 pelos onze capitalistas destacados na nota anterior superou em grande medida as hipotecas realizadas no ano, salientando a realizações de outros financiamentos.

${ }^{66}$ Selecionamos o ano de 1883 para o início das informações nos Gráficos 11 e 12 em função da maior regularidade dos dados bancários a partir desse ano. 
De forma semelhante, os prazos bancários mais amplos do que os dos capitalistas entre 1883 e 1920, porém com maior instabilidade, como podemos observar no Gráfico 12. Os bancos realizavam empréstimos na média de quase 5,5 anos e os capitalistas de menos de 2,4 anos. ${ }^{67}$ De forma até mais evidente que com as taxas de juros, houve uma equivalência dos prazos médios dos bancos e capitalistas durante a Grande Guerra, em face a uma redução expressiva dos primeiros.

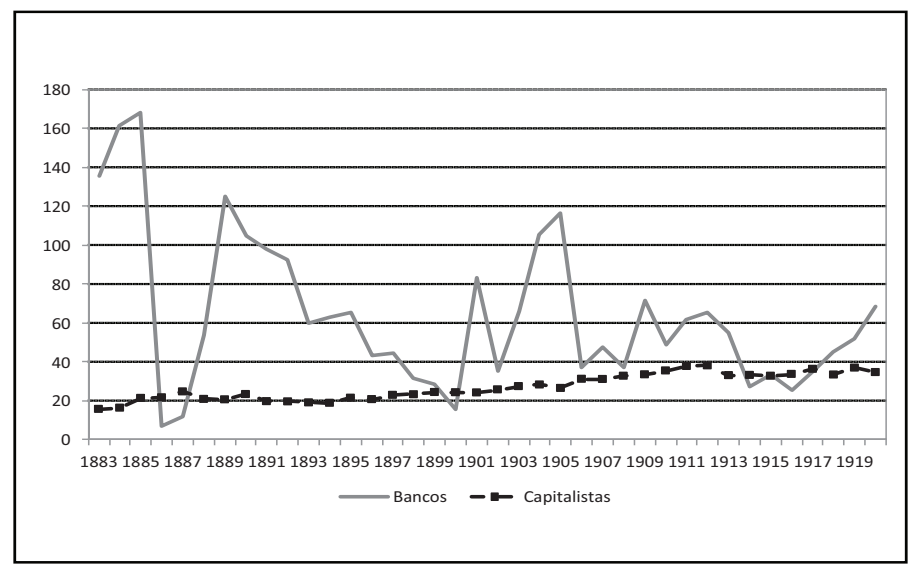

Gráfico 12 - Prazo médio em meses dos bancos e capitalistas (São Paulo, 18831920)

O mercado hipotecário dos bancos mostrou-se distinto do dos capitalistas. Os bancos emprestavam em maior frequência para industriais e pessoas jurídicas, que totalizaram nove pontos porcentuais das suas hipotecas. Os imóveis industriais oferecidos em garantia representaram quatro pontos porcentuais. Os devedores dos capitalistas eram na sua quase totalidade proprietários $(90,6 \%)$, enquanto entre os bancos tal porcentual foi de $64,0 \%$. No caso dos capitalistas, menos de um ponto porcentual dos financiados mantinham indústrias e/ou companhias, dos quais os imóveis industriais perfaziam $0,8 \%$ das garantias nesse caso. Para os capitalistas, a grande maioria dos imóveis hipotecados eram casas, perfazendo $82,9 \%$ para os de-

\footnotetext{
${ }^{67}$ A mediana e a média dos juros dos empréstimos dos capitalistas foram iguais, sendo a moda doze por cento. Os prazos médio e mediano foram idênticos e a moda dois anos. No caso dos bancos, os indicadores apresentaram melhores condições de financiamento, sendo o prazo mediano de cinco anos e a moda de dez anos. Para os juros a mediana e média também foram iguais, sendo a moda dez por cento.
} 
vedores dos capitalistas e $68,8 \%$ para os dos bancos. Os capitalistas emprestavam mais aos particulares e possivelmente para fins residenciais. O perfil do crédito hipotecário mostrou-se bastante diferenciado entre os dois tipos de credores. Os bancos concentraram-se nos clientes de maior riqueza e mais na indústria e companhias, enquanto os capitalistas emprestavam mais a miúdo, provavelmente de caráter mais residencial. Assim, o mercado hipotecário apresentava uma segmentação importante. ${ }^{68}$

\section{Considerações Finais}

O mercado de crédito privado cresceu no Brasil na segunda metade do século XIX e início do século XX, destacando as hipotecas como importante instrumento de financiamento naquela época. A dinâmica hipotecária condicionou, e foi condicionada, pelo próprio crescimento econômico e demográfico da cidade de São Paulo, que demonstrou uma expansão expressiva no mercado imobiliário nessa época. As mudanças institucionais possibilitaram a expansão do mercado hipotecário por meio de bancos e de particulares, principalmente a partir da década de 1870. O Encilhamento acentuou o crescimento anterior do número e valor das hipotecas, que não se retomou posteriormente em termos per capita. Por outro lado, as condições dos empréstimos melhoraram, principalmente para os prazos ao longo da maior parte do período. Os juros reais reduziram-se durante o Encilhamento e a Primeira Grande Guerra, em função da inflação, mas também ao longo do início do século XX.

O avanço do sistema bancário favoreceu a disponibilidade de recursos mais elevados e a melhora das condições dos empréstimos, compreendendo até mesmo a presença expressiva de instituições estrangeiras. Não obstante os valores maiores dos empréstimos bancários, o mercado hipotecário ainda se concentrava nas mãos de particulares, pois a quase totalidade das transações ocorria entre pessoas físicas. Os capitalistas realizaram um conjunto muito mais expressivo de transações do que os bancos.

${ }^{68}$ Devemos lembrar que havia outra segmentação importante que eram as debêntures, que não foram consideradas nessa seção.

Estud. Econ., São Paulo, vol.44, n.4, p.749-786, out.-dez. 2014 
Até mesmo no início do século XX, quando houve um avanço do sistema bancário expressivo no país, os capitalistas ainda efetuaram um maior número de negócios do que os bancos.

O mercado hipotecário paulistano dos agentes bancários e dos capitalistas revelou-se distinto. Os bancos emprestavam maiores quantias e a condições mais favoráveis de juros e prazos, atendendo uma demanda de companhias, como indústrias, comércio e serviços públicos. Por outro lado, os capitalistas emprestavam para um conjunto maior de pessoas, fornecendo menores valores em condições menos favorecidas, que provavelmente apresentavam maior dificuldade de recorrer aos bancos. Não obstante o mercado de crédito privado mostrar-se bastante segmentado quando analisamos as hipotecas, ele contribuiu de forma bastante expressiva para o desenvolvimento da cidade de São Paulo.

\section{Referências}

AGUIAR, P. de. Bancos no Brasil colonial: tentativas de organização bancária em Portugal e no Brasil até 1808. Salvador: Progresso, 1960.

BRITO, J. R. de. A economia brasileira no alvorecer do século XIX. Salvador: Progresso, 1923.

CATÃO, L. A. V. A new wholesale price index for Brazil during the period 1870-1913. Revista Brasileira de Economia, v. 46, n 4, out./dez. 1992, p. 519-533.

COSTA, F. N. da. Banco do Estado: o caso Banespa. Tese (Doutorado em Economia) - IE/UNICAMP, 1988.

COSTA NETO, Yttrio Corrêa da. Bancos oficiais no Brasil: origens e aspectos do seu desenvolvimento. Brasília: BCB, 2004.

FARIA, S. de C. A colônia em movimento: fortuna e família no cotidiano colonial. Rio de Janeiro: Nova Fronteira, 1998.

FERREIRA, M. de M. A crise dos comissários de café do Rio de Janeiro. Dissertação (Mestrado em História) - ICHF/UFF, 1977.

FRANCO, B. de S. Os Bancos do Brasil: sua história, defeitos da organização atual e reforma do sistema bancário. Brasília: Editora Universidade de Brasília, 1984.

FRANCO, G. Reforma monetária e instabilidade durante a transição republicana. Dissertação (Mestrado em Economia) PUC-RJ, Rio de Janeiro, BNDES, 1983.

FRANCO, G. A Primeira Década Republicana. In: ABREU, Marcelo de Paiva (org.). A Ordem do Progresso: cem anos de política econômica republicana 1889-1989. Rio de Janeiro: Campus, 1990.

GOLDSMITH, R W. Brasil 1850-1984: desenvolvimento financeiro sob um século de inflação. São Paulo: Haper \& Row, 1986. 
GUIMARÃES, C. G. O Império e o crédito hipotecário na segunda metade do século XIX: os casos do Banco Rural e Hipotecário do Rio de Janeiro e do Banco Comercial e Agrícola na década de 1850. GUIMARÃES, Elione Silva \& MOTTA, Márcia Maria Menedes (orgs.). Campos em disputa: história agrária e companhia. São Paulo: Annablume, 2007, p. 13-40.

HADDAD, C. L. S. Crescimento do produto real no Brasil. Rio de Janeiro: Ed. da FGV, 1978.

HANLEY, A. G. Native capital: financial institutions and economic development in São Paulo, Brazil, 1850-1920. Stanford: Stanford University Press, 2005.

HOFFMAN, P. T.; POSTEL-VINAY, G. \& ROSENTHAL, J-L. Priceless markets: the political economy of credit in Paris: 1660-1870. Chicago: Chicago University Press, 2000.

LAËRNE, C. F. Van Delden. Brazil and Java: report on coffee-culture in America, Asia and Africa. London: W. H. Allen, 1885.

LERIAS, R. A. Encilhamento e a cidade de São Paulo, 1890-1891. Dissertação, Mestrado em História, FFLCH/USP, 1988.

LEVY, M. B. República S. A. a economia que derrubou o Império. Ciência Hoje (SBPC). Vol. 10, nº 59, nov. 1989 , p. 34-41.

LEVY, M. B. \& ANDRADE, A. M. R. de. Fundamentos do sistema bancário no Brasil: 1834-1860. Estudos Econômicos. Vol. 15, $\mathrm{n}^{\mathrm{o}}$ especial, 1985, p. 17-48.

MACHADO, A. Vida e morte do bandeirante. Belo Horizonte/São Paulo: Ed. Itatiaia/Edusp, 1980.

MALHEIROS, A. M. Perdigão. Repertório ou indice alfabético da reforma hipotecária e sobre sociedades de crédito real. Rio de Janeiro: Typografia Nacional, 1865.

MARCONDES, R. L. \& HANLEY, A. G. Bancos na transição republicana em São Paulo: o financiamento hipotecário (1888-1901). Estudos Econômicos. Vol. 40, n. 1, 2010, p. 103-131.

MUSACCHIO, A. Experiments in financial democracy: corporate governance and financial development in Brazil, 1882-1950. New York: Cambridge University Press, 2009.

PIÑEIRO, T. L. A carteira hipotecária do Banco do Brasil: os conflitos em torno do crédito agrícola no II Reinado. GUIMARÃES, Elione Silva \& MOTTA, Márcia Maria Menedes (orgs.). Campos em disputa: história agrária e companhia. São Paulo: Annablume, 2007, p. 41-62.

PIRES, A. Café, finanças e indústria: Juiz de Fora, 1889-1930. Juiz de Fora: Funalfa, 2009.

PIRES, A. J. \& ALMICO, R. de C. da S. Crédito e finanças em uma sociedade cafeeira. História e Economia. Vol. 4, n. 2, 2008, p. 221-247.

PORTUGAL. Ordenações Filipinas: Aditamentos. Rio de Janeiro: Instituto Filomático, 1870. Disponível em http://www1.ci.uc.pt/ihti/proj/filipinas/13inda.htm

PRADO JÚNIOR, C. A cidade de São Paulo. São Paulo: Brasiliense, 1983.

RYAN Jr, J. J. Credit where credit is due: lending and borrowing in Rio de Janeiro, 1820-1900. Phd (Doctor in History) UCLA, 2007.

SAES, F. A. M. de. Crédito e bancos no desenvolvimento da economia paulista (1850-1930). São Paulo: IPE/USP, 1986.

SAMPAIO, A. C. J. de. Na curva do tempo, na encruzilhada do Império: hierarquização social e estratégias de classe na produção da exclusão (Rio de Janeiro, c.1650-c.1750). Tese (Doutorado em História) - PPH/UFF, 2000.

SCHULZ, J. A crise financeira da abolição: 1875-1901. São Paulo: Edusp: Instituto Fernand Braudel, 1996.

SCHWARTZ, S. Segredos internos: engenhos e escravos na sociedade colonial, 1550-1835. Tradução Laura Teixeira Motta. São Paulo: Companhia das Letras, 1988.

SOARES, S. F.. Esboço ou primeiros traços da crise comercial da cidade do Rio de Janeiro em 10 de setembro de 1864. Rio de Janeiro: Eduardo \& Henrique Laemmert, 1865a. 
SOARES, S. F. Elementos de estatística compreendendo a teoria da ciência e a sua aplicação à estadística comercial do Brasil. Rio de Janeiro: Typographia Nacional, 1865b.

TOPIK, S. A presença do Estado na economia política do Brasil-de 1889 a 1930. Rio de Janeiro: Record, 1987.

TRINER, G. D. Banking and economic development: Brazil, 1889-1930. New York: Palgrave, 2000.

WERNECK, L. P. de L. Estudos sobre o crédito rural e hipotecário seguidos de leis, estatutos e outros documentos. Rio de Janeiro: Casa de B. L. Garnier, 1857.

WILEMAN. The Brazilian Review: a weekly record of trade and finance. Rio de Janeiro, 1903-04, vários números.

\section{Apêndice Estatístico}

Número e valor das hipotecas paulistanas (1865-1928)

\begin{tabular}{|c|c|c|}
\hline Ano & Número de hipotecas & Valor Nominal em contos de réis \\
\hline 1865 & 31 & 113 \\
\hline 1866 & 76 & 206 \\
\hline 1867 & 53 & 154 \\
\hline 1868 & 44 & 671 \\
\hline 1869 & 36 & 67 \\
\hline 1870 & 36 & 132 \\
\hline 1871 & 49 & 206 \\
\hline 1872 & 46 & 358 \\
\hline 1873 & 44 & 165 \\
\hline 1874 & 58 & 171 \\
\hline 1875 & 52 & 155 \\
\hline 1876 & 61 & 191 \\
\hline 1877 & 81 & 278 \\
\hline 1878 & 109 & 2.706 \\
\hline 1879 & 95 & 448 \\
\hline 1880 & 138 & 853 \\
\hline 1881 & 170 & 496 \\
\hline 1882 & 255 & 1.265 \\
\hline 1883 & 301 & 1.148 \\
\hline 1884 & 280 & 1.349 \\
\hline 1885 & 310 & 2.187 \\
\hline 1886 & 323 & 1.621 \\
\hline 1887 & 378 & 1.888 \\
\hline 1888 & 602 & 3.541 \\
\hline 1889 & 694 & 4.547 \\
\hline 1890 & 963 & 13.188 \\
\hline 1891 & 1.197 & 26.861 \\
\hline 1892 & 1.252 & 78.719 \\
\hline 1893 & 1.065 & 37.953 \\
\hline 1894 & 1.128 & 14.712 \\
\hline 1895 & 1.145 & 17.380 \\
\hline 1896 & 1.273 & 16.179 \\
\hline
\end{tabular}


Número e valor das hipotecas paulistanas (1865-1928) (Continuação)

\begin{tabular}{|c|c|c|}
\hline 1897 & 1.693 & 21.546 \\
\hline 1898 & 1.715 & 20.571 \\
\hline 1899 & 1.448 & 20.143 \\
\hline 1900 & 1.208 & 16.091 \\
\hline 1901 & 974 & 49.653 \\
\hline 1902 & 889 & 13.839 \\
\hline 1903 & 1.063 & 16.547 \\
\hline 1904 & 1.100 & 17.106 \\
\hline 1905 & 1.156 & 83.941 \\
\hline 1906 & 1.150 & 15.661 \\
\hline 1907 & 1.216 & 13.509 \\
\hline 1908 & 1.484 & 19.774 \\
\hline 1909 & 1.917 & 18.372 \\
\hline 1910 & 2.134 & 27.537 \\
\hline 1911 & 2.507 & 90.173 \\
\hline 1912 & 3.114 & 81.537 \\
\hline 1913 & 3.847 & 93.831 \\
\hline 1914 & 3.824 & 114.977 \\
\hline 1915 & 3.259 & 61.580 \\
\hline 1916 & 2.592 & 70.915 \\
\hline 1917 & 2.480 & 52.076 \\
\hline 1918 & 2.304 & 52.809 \\
\hline 1919 & 2.464 & 62.794 \\
\hline 1920 & 2.916 & 77.837 \\
\hline 1921 & 3.653 & 115.414 \\
\hline 1922 & 4.061 & 139.226 \\
\hline 1923 & 5.118 & 245.680 \\
\hline 1924 & 5.180 & 214.916 \\
\hline 1925 & 6.097 & 350.749 \\
\hline 1926 & 6.775 & 280.240 \\
\hline 1927 & 7.361 & 303.362 \\
\hline 1928 & 7.614 & 345.602 \\
\hline TOTAL & 106.806 & 3.337.922 \\
\hline
\end{tabular}

